\title{
DISTINCT ROLES FOR PROTEIN KINASE C ISOFORMS IN REGULATING PLATELET PURINERGIC RECEPTOR FUNCTION
}

Stuart J. Mundell, Matthew L. Jones, Adam R. Hardy, Johanna F. Barton, Stephanie M. Beaucourt, Pamela B. Conley and Alastair W. Poole

From the Department of Pharmacology, School of Medical Sciences, University Walk, Bristol BS8 1TD, UK (SJM, MLJ, ARH, JFB \& AWP).

Henry Wellcome Laboratories for Integrative Neuroscience and Endocrinology, Dorothy Hodgkin Building, Whitson Street, Bristol BS1 3NY, UK (SMB).

Portola Pharmaceuticals Inc., 270 East Grand Ave., ste 22, South San Francisco, CA 94080, USA (PBC). 


\section{RUNNING TITLE: P2Y 1 AND P2Y 12 ARE DIFFERENTIALLY REGULATED BY PKCS $\alpha$ AND $\delta$}

Address correspondence to: Alastair W. Poole, Department of Pharmacology, School of Medical Sciences, University Walk, Bristol, BS8 1TD, United Kingdom. Tel.: + 44117928 7635. FAX: + 44117925 0168. email: a.poole@bris.ac.uk.

Number of text pages: 34

Numbers of Tables: $\quad 0$

Number of Figures: 7

Number of references: 44

Number of words in the Abstract: $\quad 250$

Number of words in the Introduction: 423

Number of words in the Discussion: 1749

Non-standard abbreviations: GPCR, G protein-coupled receptor; DMEM, Dulbecco's modified Eagle's medium; DNM, dominant negative mutant; PMA, phorbol 12-myristate 13-acetate; PBS, phosphatebuffered saline; ECL, enhanced chemiluminescence; HEPES, N-[2-hydroxyethyl] piperazine-N-[2ethanesulphonic acid]; ACD, Acid citrate dextrose; IBMX, isobutyl methylxanthine; A3P5P, adenosine3', 5'-diphosphate; 2MeSADP, 2-methylthioadenosine 5'-diphosphate. 


\begin{abstract}
ADP is a critical regulator of platelet activation, mediating its actions through two G protein-coupled receptors (GPCRs), $\mathrm{P}^{2} \mathrm{Y}_{1}$ and $\mathrm{P} 2 \mathrm{Y}_{12}$. We had previously shown the receptors to be functionally desensitised, in a homologous manner, by distinct kinase-dependent mechanisms, where $\mathrm{P}_{2} \mathrm{Y}_{1}$ is regulated by protein kinase $\mathrm{C}(\mathrm{PKC})$ and $\mathrm{P} 2 \mathrm{Y}_{12}$ by $\mathrm{G}$ protein-coupled receptor kinases (GRKs). Here we have addressed whether different PKC isoforms play different roles in regulating the trafficking and activity of these two GPCRs. Expression of PKC $\alpha$ and PKC $\delta$ dominant negative mutants in $1321 \mathrm{~N} 1$ cells revealed that both isoforms regulated $\mathrm{P} 2 \mathrm{Y}_{1}$ receptor signalling and trafficking whilst only $\mathrm{PKC} \delta$ was capable of regulating $\mathrm{P}_{2} \mathrm{Y}_{12}$, in experiments where $\mathrm{PKC}$ was directly activated by the phorbol ester PMA. These results were paralleled in human platelets, where PMA reduced subsequent ADP-induced $\mathrm{P} 2 \mathrm{Y}_{1}$ and $\mathrm{P} 2 \mathrm{Y}_{12}$ receptor signalling. PKC isoform-selective inhibitors revealed that novel, but not classical, isoforms of $\mathrm{PKC}$ regulate $\mathrm{P} 2 \mathrm{Y}_{12}$ function, whilst both novel and classical isoforms regulate $\mathrm{P} 2 \mathrm{Y}_{1}$ activity. Importantly also we studied receptor internalisation in platelets by a radioligand binding approach, that showed that both receptors internalise rapidly in these cells. ADP-induced $\mathrm{P}_{2} \mathrm{Y}_{1}$ receptor internalisation is attenuated by $\mathrm{PKC}$ inhibitors, whilst that of the $\mathrm{P}_{2} \mathrm{Y}_{12}$ receptor is unaffected. Both $\mathrm{P}_{2} \mathrm{Y}_{1}$ and $\mathrm{P} 2 \mathrm{Y}_{12}$ receptors can also undergo PMA-stimulated internalization, and here again novel but not classical PKCs regulate $\mathrm{P} 2 \mathrm{Y}_{12}$ whilst both novel and classical isoforms regulate $\mathrm{P}_{2} \mathrm{Y}_{1}$ internalization. This study therefore is the first to reveal distinct roles for PKC isoforms in the regulation of platelet P2Y receptor function and trafficking.
\end{abstract}


Molecular Pharmacology Fast Forward. Published on June 27, 2006 as DOI: 10.1124/mol.106.023549

This article has not been copyedited and formatted. The final version may differ from this version.

$\operatorname{MOL}(2006 / 023549)$

\section{INTRODUCTION}

Activation of platelets occurs through a complex series of reactions in response to vessel injury and plays an essential role in thrombosis. One agonist, adenosine diphosphate (ADP), plays a central role in platelet activation by acting as a cofactor in the platelet responses to physiological agonists, including thromboxane A2, collagen, and thrombin. ADP activates two surface expressed GPCRs, P2 $\mathrm{Y}_{1}$ and P2 $\mathrm{Y}_{12}$ (Gachet, 2005; Kunapuli et al., 2003). The combined stimulation of $\mathrm{P} 2 \mathrm{Y}_{1}$ receptor (coupled to $\mathrm{G}_{\mathrm{q}}$ and PLC $\beta$ ) and $P 2 Y_{12}$ receptor (negatively coupled to adenylyl cyclase through $G_{i}$ ) is necessary for the full platelet aggregation response to ADP with platelet activation initiated by the $\mathrm{P}_{2} \mathrm{Y}_{1}$ receptor and amplified by $\mathrm{P} 2 \mathrm{Y}_{12}$ (Gachet, 2005).

The attenuation of receptor-stimulated signal output upon sustained or recurrent agonist stimulation, a process known as desensitisation, is a crucial physiological mechanism of adaptation observed for many GPCRs. Since ADP plays a crucial role in platelet activation it likely that the responsiveness of P2 $\mathrm{Y}_{1}$ and $\mathrm{P} 2 \mathrm{Y}_{12}$ receptors is tightly regulated. Recently we showed that both $\mathrm{P} 2 \mathrm{Y}_{1}$ and $\mathrm{P} 2 \mathrm{Y}_{12}$ receptor responses desensitise in human platelets (Hardy et al., 2005) which may underlie the observed desensitisation of platelet responses following prolonged exposure to ADP (Baurand et al., 2000; Poole et al., 1993). Mechanisms underlying desensitization are complex and can involve phosphorylation of the receptor, uncoupling from $\mathrm{G}$ proteins, internalization, and ultimately intracellular down-regulation (Ferguson, 2001; von Zastrow, 2003). We have recently discovered that ADP pre-treatment promotes $\mathrm{P}_{2} \mathrm{Y}_{1}$ and $\mathrm{P}_{2} \mathrm{Y}_{12}$ receptor desensitization by different kinase-dependent mechanisms. $\mathrm{P} 2 \mathrm{Y}_{1}$, but not $\mathrm{P} 2 \mathrm{Y}_{12}$, desensitization is mediated by protein kinase C (PKC) (Hardy et al., 2005). In contrast, agonist-induced desensitization of the $\mathrm{P} 2 \mathrm{Y}_{12}$ receptor, but not $\mathrm{P} 2 \mathrm{Y}_{1}$, is largely dependent on $\mathrm{G}$ protein-receptor coupled kinases (GRKs) activity.

It is now important to address several important questions that are raised by our previous work: (i) since platelets express multiple isoforms of PKC (Buensuceso et al., 2005; Crosby and Poole, 2002; Murugappan et al., 2004), which isoforms are responsible for mediating homologous desensitisation of the $\mathrm{P} 2 \mathrm{Y}_{1}$ receptor? (ii) given the fact that platelets express multiple Gq-coupled receptors, each leading to 
Molecular Pharmacology Fast Forward. Published on June 27, 2006 as DOI: 10.1124/mol.106.023549

This article has not been copyedited and formatted. The final version may differ from this version.

$\operatorname{MOL}(2006 / 023549)$

activation of $\mathrm{PKC}$, can activation of $\mathrm{PKC}$ cause 'heterologous' regulation of $\mathrm{P} 2 \mathrm{Y}_{12}$, and if so which isoforms of PKC are involved?, (iii) do the receptors themselves become phosphorylated by PKC? Although our previous work had addressed only the roles of kinases in regulating functional desensitisation of the receptors, it is now also important to address their role in receptor internalisation and trafficking. In this study we address these questions and reveal distinct roles for PKC isoforms in the regulation of platelet $\mathrm{P} 2 \mathrm{Y}$ receptor function and trafficking. 
Molecular Pharmacology Fast Forward. Published on June 27, 2006 as DOI: 10.1124/mol.106.023549

This article has not been copyedited and formatted. The final version may differ from this version.

$\operatorname{MOL}(2006 / 023549)$

\section{MATERIALS AND METHODS}

Materials - Dulbecco's modified Eagle's medium (DMEM), Lipofectamine 2000 and fetal bovine serum were obtained from Life Technologies Inc. Radiochemicals were from Perkin Elmer Life Sciences. Complete protease inhibitor tablets were from Roche. Anti-HA-monoclonal antibody (HA-11), goat antimouse fluorescein-conjugated secondary antibody (1:200), rhodamine-conjugated transferrin and lysotracker red were purchased from Molecular Probes. The bisindolylmaleimide GF109203X (2-[1-(3dimethylaminopropyl)-1H- indol-3-yl]-3-(1H-indol-3-yl)-maleimide), Gö6976 [12-(2-Cyanoethyl)6,7,12,13-tetrahydro-13-methyl-5-oxo-5H-indolo(2,3-a)pyrrolo(3,4-c)-carbazole] and rottlerin were from Calbiochem (Merck Biosciences Ltd, Nottingham, UK). All other reagents were from Sigma.

Adenovirus infection and cell culture - Expression vectors for dominant negative mutant (DNM) PKC $\alpha$ (rabbit) and PKC $\delta$ (mouse) in adenoviruses were kind gifts from Professors Motoi Ohba and Toshio Kuroki, and have been described previously (Mitsutake et al., 2001; Ohba et al., 1998). Adenoviruses were amplified in HEK293 cells and harvested after 72 hours, purified and viral titers estimated as previously described (Kanegae et al., 1994). 1321N1 human astrocytoma cells stably expressing either hemagglutinin (HA)-tagged human $\mathrm{P} 2 \mathrm{Y}_{1}$ or $\mathrm{P} 2 \mathrm{Y}_{12}$ receptor were generated as previously described (Hardy

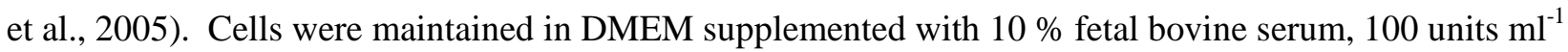
penicillin G, $100 \mu \mathrm{g} \mathrm{ml}^{-1}$ streptomycin sulfate and $400 \mu \mathrm{g} / \mathrm{ml}$ geneticin at $37{ }^{\circ} \mathrm{C}$ supplemented with in a humidified atmosphere of $95 \%$ air, $5 \% \mathrm{CO}_{2}$. For adenoviral infection, $1321 \mathrm{~N} 1$ cells were infected at between 50-200 pfu/cell in serum-free DMEM for 2 hours. Infection with empty vector $\beta$-gal adenovirus was used as control.

Receptor phosphorylation - Stably transfected cells in six well dishes were twice with phosphate-free DMEM and incubated for $90 \mathrm{~min}$ at $37{ }^{\circ} \mathrm{C}$ in the same media supplemented with $0.2 \mathrm{mCi} / \mathrm{ml}\left[{ }^{32} \mathrm{P}\right]$ 
Molecular Pharmacology Fast Forward. Published on June 27, 2006 as DOI: 10.1124/mol.106.023549

This article has not been copyedited and formatted. The final version may differ from this version.

$\operatorname{MOL}(2006 / 023549)$

orthophosphate and 0.2 unit / ml apyrase. After incubation with the PKC inhibitor GF109203X (1 $\mu$ M; 15 min) or vehicle alone cells were treated with either $\mathrm{ADP}(10 \mu \mathrm{M} ; 5 \mathrm{~min})$ or the protein kinase $\mathrm{C}$ activator phorbol 12-myristate 13-acetate (PMA; $1 \mu \mathrm{M} ; 15 \mathrm{~min}$ ). Following drug treatment, reactions were terminated by placing the cells on ice and washing twice with ice cold PBS. All subsequent procedures were performed at $4{ }^{\circ} \mathrm{C}$ unless otherwise stated. Cells were subsequently lysed and HA-tagged receptor immunoprecipitated using a monoclonal anti-HA antibody (HA-11) as previously described (Mundell et al., 2004). Immune complexes were isolated by brief centrifugation, washed three times with immunoprecipitation buffer and eluted from beads by the addition of $20 \mu$ electrophoresis sample buffer. After fractionation by SDS-PAGE and transfer to a nitrocellulose membrane, phosphoproteins were visualised by autoradiography for $24-72 \mathrm{hr}$ at $-80{ }^{\circ} \mathrm{C}$. Receptor immunoprecipitation was determined by reprobing membranes with a polyclonal anti-HA antibody / horse radish peroxidase-conjugated antirabbit IgG and visualization by enhanced chemiluminescence (ECL). The extent of receptor phosphorylation was quantified by densitometric analysis of resulting autoradiographs.

Western Blotting - Protein expression in 1321N1 cells and platelets was determined by western blotting. Briefly, cells were lysed into ice-cold lysis buffer (HEPES 20 mM, pH 7.4, NaCl 200 mM, EDTA 10 mM, 1\% Triton X-100, supplemented with Complete protease inhibitors), insoluble material discarded by centrifugation $(13,000 \mathrm{~g}, 5 \mathrm{~min})$ and sodium dodecyl sulphate (SDS) loading buffer (63 $\mathrm{mM}$ Tris, $\mathrm{pH} 6.5$, $100 \mathrm{mM}$ dithiothreitol, $1 \%$ SDS, $11.6 \%$ glycerol and $0.02 \%$ bromophenol blue) added to the cell lysates. Proteins were separated by SDS-PAGE. Gels were transferred to nitrocellulose membranes and blotted with PKC isoform specific antibodies for PKC $\alpha, \beta$, (Zhang et al., 2001), $\delta$ and $\theta$ (Blass et al., 2002). Proteins were detected by enhanced chemiluminescence (ECL).

Measurement of cytosolic free calcium $\left(\left[\mathrm{Ca}^{2+}\right]_{i}\right)$ in $1321 \mathrm{N1}$ astrocytoma cells - The cytosolic free $\mathrm{Ca}^{2+}$ concentration was determined using the fluorescent $\mathrm{Ca}^{2+}$ indicator fura-2-acetoxymethyl ester (fura-2/AM) 
as previously reported (Hardy et al., 2005). Briefly transfected cells were grown on poly-L-lysine coated glass coverslips and used at $\sim 60 \%$ confluence. Cells were washed twice with Locke's solution (154 mM $\mathrm{NaCl}$, 5.6 mM KCL, 1.2mM $\mathrm{MgCl}_{2}, 2.2 \mathrm{mM} \mathrm{CaCl}_{2}, 5 \mathrm{mM}$ HEPES, $10 \mathrm{mM}$ glucose, $\mathrm{pH}$ 7.4) and incubated with fura-2/AM $(3 \mu \mathrm{M})$ at $37^{\circ} \mathrm{C}$ for 60 mins. Glass coverslips were mounted into a quartz cuvette and placed into a thermostatically-controlled cell holder at $37{ }^{\circ} \mathrm{C}$. Cells were continuously perfused with Lockes solution. Fluorescence was measured at 340 and $380 \mathrm{nM}$ excitation and $510 \mathrm{nM}$ emission. ADP $(0.1-1 \mu \mathrm{M})$ was perfused onto cell monolayers as required. $\left[\mathrm{Ca}^{2+}\right]_{\mathrm{i}}$ was determined from ratiometric data as previously described (Grynkiewicz et al., 1985).

Measurement of cAMP accumulation in 1321N1 astrocytoma cells - Cells infected with PKC-DNM adenoviruses, or $\beta$-gal alone controls, as described above were grown to $80 \%$ confluency and exposed to a desensitising dose of $\mathrm{ADP}(1 \mathrm{nM} ; 15 \mathrm{~min})$ or PMA $(1 \mu \mathrm{M} ; 15 \mathrm{~min})$ in the presence of the phosphodiesterase inhibitor Ro201724 $(250 \mu \mathrm{M})$. Apyrase $(0.2$ unit $/ \mathrm{ml})$ was then added directly to each well and incubated for $1 \mathrm{~min}$ at $37{ }^{\circ} \mathrm{C}$ to remove the desensitising ADP. Cells were then washed and forskolin $(1 \mu \mathrm{M})$ added in the absence or presence of ADP and plates incubated at $37^{\circ} \mathrm{C}$ for 10 minutes. Endogenous $\beta_{2}$ adrenoceptor responses were also examined in $1321 \mathrm{~N} 1$ cells by measuring isoproterenol ( 1 $\mu \mathrm{M})$-stimulated cAMP accumulation. Cyclic AMP accumulation was terminated by addition of ice cold $100 \%$ trichloroacetic acid and supernatant neutralized with $1 \mathrm{M} \mathrm{NaOH}$ and TE buffer. Cyclic AMP levels were determined as previously described (Mundell et al., 1997). Data are expressed as cAMP production (pmol cAMP/well) or as \% inhibition of forskolin stimulated adenylyl cyclase.

Internalization of HA-P2Y $Y_{1}$ and HA-P2 $Y_{12}$ in 1321N1cells - HA-tagged surface receptor loss was assessed by ELISA as described previously (Daunt et al., 1997; Mundell et al., 2000). Cells were split into 24-well tissue culture dishes coated with $0.1 \mathrm{mg} \mathrm{ml}^{-1}$ poly-L-lysine. Twenty-four hours later, cells were incubated with DMEM containing apyrase $(0.1 \mathrm{unit} / \mathrm{ml})$ for 1 hour at $37^{\circ} \mathrm{C}$, washed and then pre-treated with the 
Molecular Pharmacology Fast Forward. Published on June 27, 2006 as DOI: 10.1124/mol.106.023549

This article has not been copyedited and formatted. The final version may differ from this version.

$\operatorname{MOL}(2006 / 023549)$

PKC inhibitor GF109203X (1 $\mu \mathrm{M} ; 15 \mathrm{~min})$. Cells were then challenged with DMEM containing ADP (10 $\mu \mathrm{M} ; 15 \mathrm{~min})$ or PMA $(1 \mu \mathrm{M} ; 15 \mathrm{~min})$ at $37{ }^{\circ} \mathrm{C}$. Changes in surface receptor expression were subsequently determined by an immunosorbent assay (ELISA) taking advantage of the HA-epitope tag (Daunt et al., 1997; Mundell et al., 2000), and expressed as either \% surface receptor or \% loss of surface receptor with the background signal from controls subtracted.

Preparation of human platelets - Human blood was drawn from healthy, drug-free volunteers on the day of the experiment. Acid citrate dextrose (ACD: $120 \mathrm{mM}$ sodium citrate, $110 \mathrm{mM}$ glucose, $80 \mathrm{mM}$ citric acid, used at 1:7 vol/vol) was used as anticoagulant. Platelet rich plasma (PRP) was prepared by centrifugation at $200 \mathrm{~g}$, for $17 \mathrm{~min}$ and platelets were then isolated by centrifugation for $10 \mathrm{~min}$ at $1000 \mathrm{~g}$, in the presence of $0.02 \mathrm{U} / \mathrm{ml}$ apyrase and prostaglandin $\mathrm{E}_{1}\left(\mathrm{PGE}_{1} ; 140 \mathrm{nM}\right)$ for all assays other than measurement of intracellular cyclic AMP (cAMP) where PGE $_{1}$ was omitted. The pellet was resuspended to a density of $4 \times 10^{8}$ platelets $/ \mathrm{ml}$ in a modified Tyrodes-HEPES buffer $(145 \mathrm{mM} \mathrm{NaCl}, 2.9 \mathrm{mM} \mathrm{KCl}, 10$ $\mathrm{mM}$ HEPES, $1 \mathrm{mM} \mathrm{MgCl} 2,5 \mathrm{mM}$ glucose, $\mathrm{pH}$ 7.3). To this platelet suspension $10 \mu \mathrm{M}$ indomethacin and $0.02 \mathrm{U} / \mathrm{ml}$ apyrase were added, and a $30 \mathrm{~min}$ resting period was allowed before stimulation.

Measurement of cytosolic free calcium $\left(\left[\mathrm{Ca}^{2+}\right]_{i}\right)$ in platelets - Measurement of cytosolic calcium was performed as previously described (Poole et al., 1995). Briefly, $3 \mu \mathrm{M}$ Fura-2-AM was added to platelet rich plasma, and incubated at $37{ }^{\circ} \mathrm{C}$ for $45 \mathrm{~min}$ in the presence of $10 \mu \mathrm{M}$ indomethacin. Platelets were centrifuged and re-suspended in modified Tyrodes. Platelets were treated for 15 min with the PKC inhibitors GF109203X (2 $\mu \mathrm{M})$, Gö6976 $(1 \mu \mathrm{M})$ Rottlerin $(10 \mu \mathrm{M})$ or vehicle alone. ADP $(10 \mu \mathrm{M})$ induced calcium responses were subsequently measured at $37^{\circ} \mathrm{C}$ in PMA $(1 \mu \mathrm{M} ; 15 \mathrm{~min})$ and non PMAtreated platelets using a Hitachi F-4500 spectrofluorimeter with fluorescence excitation made at $340 \mathrm{~nm}$ and $380 \mathrm{~nm}$ and emission at $510 \mathrm{~nm}$. 
Molecular Pharmacology Fast Forward. Published on June 27, 2006 as DOI: 10.1124/mol.106.023549

This article has not been copyedited and formatted. The final version may differ from this version.

$\operatorname{MOL}(2006 / 023549)$

Measurement of cAMP levels in platelets - Platelets were treated for 15 min with the PKC inhibitors GF109203X (2 $\mu \mathrm{M})$, Gö6976 $(1 \mu \mathrm{M})$, rottlerin $(10 \mu \mathrm{M})$ or vehicle alone. PMA (1 $\mu \mathrm{M} ; 15 \mathrm{~min})$ and non PMA-treated platelets were stimulated in the presence of the phosphodiesterase inhibitor IBMX (100 $\mu \mathrm{M})$ \pm forskolin $(1 \mu \mathrm{M})$ in the absence or presence of $\mathrm{ADP}(10 \mu \mathrm{M})$ for $5 \mathrm{~min}$ at $37{ }^{\circ} \mathrm{C}$. Cyclic AMP accumulation was terminated by addition of ice cold $100 \%$ trichloroacetic acid (TCA) and samples were left to lyse on ice for 1-2 hrs. The resulting samples were spun at $4000 \mathrm{~g}$ for $5 \mathrm{~min}$ and the cAMPcontaining supernatant neutralized with $1 \mathrm{M} \mathrm{NaOH}$ and TE buffer $(50 \mathrm{mM}$ Tris-HCl, $4 \mathrm{mM}$ EDTA, pH 7.4). Cyclic AMP levels were subsequently determined in each sample using a binding assay as previously described (Mundell et al., 1997). Data are presented as either \% inhibition of forskolinstimulated adenylyl cyclase.

Radioligand binding in human platelets - In experiments assessing receptor internalization platelets were pre-treated with the PKC inhibitors with GF109203X $(2 \mu \mathrm{M})$, Gö6976 $(1 \mu \mathrm{M})$ Rottlerin $(10 \mu \mathrm{M})$ or vehicle alone. Platelets were subsequently stimulated with ADP (10 $\mu \mathrm{M}$ 0-30 min), PMA (1 $\mu \mathrm{M} 15 \mathrm{~min})$ or vehicle alone. ADP was then removed by addition of $0.2 \mathrm{U} / \mathrm{ml}$ apyrase for $3 \mathrm{~min}$ prior to fixing platelets. Platelets were fixed by continuous rotation for 25 minutes in the presence of $4 \%$ formaldehyde. Platelets were then isolated by centrifugation at $1000 \mathrm{~g}(10 \mathrm{~min})$ and then resuspended in binding buffer (20 $\mathrm{mM}$ HEPES, $1 \mathrm{mM} \mathrm{MgCl}_{2}$ ) to a density of $4 \times 10^{8}$ platelets $/ \mathrm{ml}$. Aliquots of platelet suspension were incubated with $\left[{ }^{3} \mathrm{H}\right]-2 \mathrm{MeSADP}(3 \mathrm{Ci} / \mathrm{mmol} ; 0.01 \mathrm{nM}-1 \mu \mathrm{M})$ and specific binding determined in the presence of either unlabelled ligand $(10 \mu \mathrm{M})$, the $\mathrm{P} 2 \mathrm{Y}_{1}$ receptor antagonist A3P5P $(1 \mu \mathrm{M}-3.33 \mathrm{mM})$ or the $\mathrm{P}_{2} \mathrm{Y}_{12}$ receptor antagonist AR-C69931MX (1 nM- $\left.10 \mu \mathrm{M}\right)$. Following incubation for 20 minutes at room temperature reactions were terminated by addition of ice cold binding buffer and rapid filtration through Whatman GF/C glass fibre filters under vacuum. Radioactivity bound to the filters was measured by scintillation counting. 
Molecular Pharmacology Fast Forward. Published on June 27, 2006 as DOI: 10.1124/mol.106.023549

This article has not been copyedited and formatted. The final version may differ from this version.

$\operatorname{MOL}(2006 / 023549)$

Experimental design and statistics - Data were analysed by the iterative fitting program GraphPAD Prism (GraphPAD Software). Log concentration-effect curves were fitted to logistic expressions for single-site analysis, whilst $\mathrm{t}_{0.5}$ values for agonist-induced internalization were obtained by fitting data to single exponential curves. Where appropriate, statistical significance was assessed by Mann-Whitney-U test or by two-way ANOVA. 


\section{RESULTS}

PKC-dependent $P 2 Y_{1}$ and $P 2 Y_{12}$ receptor phosphorylation - No studies to date have demonstrated the direct phosphorylation of either the $\mathrm{P}_{2} \mathrm{Y}_{1}$ or $\mathrm{P} 2 \mathrm{Y}_{12}$ purinergic receptor although both contain multiple potential phosphorylation sites with their C-terminal domain. At this time the lack of specific $\mathrm{P} 2 \mathrm{Y}_{1}$ and $\mathrm{P}_{2} \mathrm{Y}_{12}$ receptor antibodies able to consistently identify and immunoprecipitate receptor from platelets precluded studies of endogenous purinergic receptor phosphorylation. Therefore, we examined the phosphorylation of heterologously expressed HA epitope-tagged $\mathrm{P} 2 \mathrm{Y}_{1}$ and $\mathrm{P} 2 \mathrm{Y}_{12}$ receptors in $\mathrm{P} 2 \mathrm{Y}$ null $1321 \mathrm{~N} 1$ cells. A polyclonal anti-HA antibody recognised specific immunoreactive bands in membranes from both $\mathrm{P} 2 \mathrm{Y}_{1}$ and $\mathrm{P} 2 \mathrm{Y}_{12}$ receptor expressing cells (Fig. 1). These bands at $45 \mathrm{kDa}\left(\mathrm{P} 2 \mathrm{Y}_{1}\right)$ or $70 \mathrm{kDa}$ $\left(\mathrm{P} 2 \mathrm{Y}_{12}\right)$ were not present in vector alone pcNEO transfected controls, and run at apparent molecular weights consistent with other reports (Moran-Jimenez and Matute, 2000; Zhong et al., 2004). P2Y 12 receptor runs at a considerably higher apparent molecular weight than may be predicted from its primary amino acid sequence, due to extensive N-linked glycosylation (Zhong et al., 2004). P2 $\mathrm{Y}_{1}$ receptor has been shown to have an apparent molecular weight of 40-50 kDa by electrophoretic mobility (MoranJimenez and Matute, 2000). Phosphorylation studies revealed that both $\mathrm{P} 2 \mathrm{Y}_{1}$ and $\mathrm{P} 2 \mathrm{Y}_{12}$ receptors exist as phosphoproteins under basal conditions and that addition of either ADP (10 $\mu \mathrm{M} ; 5 \mathrm{~min})$ or the PKC activator phorbol 12-myristate 13-acetate (PMA; $1 \mu \mathrm{M} ; 15 \mathrm{~min}$ ) significantly increased receptor phosphorylation. Pre-treatment with the PKC inhibitor GF109203X (1 $\mu \mathrm{M} ; 15 \mathrm{~min})$ significantly attenuated $\mathrm{ADP}$ and PMA promoted $\mathrm{P}_{2} \mathrm{Y}_{1}$ receptor phosphorylation. Therefore PKC can directly phosphorylate either the agonist occupied or unoccupied $\mathrm{P}_{2} \mathrm{Y}_{1}$ receptor. In contrast GF109203X only attenuated PMA promoted $\mathrm{P} 2 \mathrm{Y}_{12}$ receptor phosphorylation. Therefore agonist-induced $\mathrm{P} 2 \mathrm{Y}_{12}$ receptor phosphorylation is not regulated by PKC although this kinase can directly phosphorylate the agonist unoccupied receptor. 
Molecular Pharmacology Fast Forward. Published on June 27, 2006 as DOI: 10.1124/mol.106.023549

This article has not been copyedited and formatted. The final version may differ from this version.

$\operatorname{MOL}(2006 / 023549)$

PKC-dependent desensitization of $P 2 Y_{1}$ and $P 2 Y_{12}$ receptor activity in $1321 N 1$ cells - To identify more accurately the $\mathrm{PKC}$ isoforms that may regulate $\mathrm{P} 2 \mathrm{Y}_{1}$ and $\mathrm{P} 2 \mathrm{Y}_{12}$ receptor function we examined their expression in both $1321 \mathrm{~N} 1$ cells and human platelets. Western blotting revealed that although platelets expressed PKCs $\alpha, \beta, \delta$ and $\theta, 1321 \mathrm{~N} 1$ cells expressed only PKC $\alpha$ and $\mathrm{PKC} \delta$ (Fig. 2A). We therefore subsequently over-expressed dominant negative catalytically inactive mutants of both of these isoforms in $1321 \mathrm{~N} 1$ cells, by an adenoviral infection approach (Fig. 2B, where immunoblotting for both PKC $\alpha$ and $\mathrm{PKC} \delta$ is shown), and examined effects of expression upon receptor signalling and internalisation. $\mathrm{P}^{2} \mathrm{Y}_{1}$ receptor desensitisation was examined by monitoring the cytosolic calcium response to ADP, as we have previously shown (Hardy et al., 2005). Over-expression of either isoform-specific dominant negative mutant (DNM) did not significantly attenuate agonist-induced desensitisation (Fig. 3A). A reduction in $\mathrm{P}_{2} \mathrm{Y}_{1}$ receptor desensitisation was only apparent in cells co-expressing both $\mathrm{PKC} \alpha$ - and PKC $\delta$-DNM (Fig. 3A). Pre-treatment with PMA $(1 \mu \mathrm{M} ; 15 \mathrm{~min})$ significantly attenuated subsequent agonist-induced $\mathrm{P}_{2} \mathrm{Y}_{1}$ receptor activity. As with the homologous desensitisation of $\mathrm{P}_{2} \mathrm{Y}_{1}$ receptor activity, heterologous PMAinduced desensitisation was only attenuated when both PKC $\alpha$ - and PKC $\delta$-DNM were co-expressed. Studies examining the $\mathrm{G}_{\mathrm{i}}$-coupled $\mathrm{P} 2 \mathrm{Y}_{12}$ purinergic receptor revealed that ADP-induced inhibition of forskolin-stimulated adenylyl cyclase (ADP induced an 80\% inhibition of response, consistent with previous studies (Hardy et al., 2005)) was reduced following PMA (1 $\mu \mathrm{M} ; 15$ min) pre-treatment to a similar extent to that found in ADP (10 nM; $15 \mathrm{~min}$ ) desensitised cells (Fig. 3B). Actual numbers are shown in Fig. 3B(i) and normalised data is shown in Fig. 3B(ii). Data from Fig. 3B(i) also shows that PMA is not able to induce activation of adenylyl cyclase, nor inhibit forskolin-induced activity of the cyclase. Therefore $\mathrm{PKC}$ can regulate the agonist unoccupied $\mathrm{P} 2 \mathrm{Y}_{12}$ purinergic receptor in a heterologous manner. Over-expression of DNM-PKC $\delta$, and not DNM-PKC $\alpha$ selectively attenuated PMA-induced P2Y 12 purinergic receptor desensitisation whilst ADP-induced desensitisation was unaffected by either DNM PKC. 
Molecular Pharmacology Fast Forward. Published on June 27, 2006 as DOI: 10.1124/mol.106.023549

This article has not been copyedited and formatted. The final version may differ from this version.

$\operatorname{MOL}(2006 / 023549)$

PKC-dependent internalization of $P 2 Y_{1}$ and $P 2 Y_{12}$ receptors in $1321 N 1$ cells - Using $1321 \mathrm{~N} 1$ cells stably expressing N-terminal HA-epitope tagged versions of either receptor we are able to quantify agonistinduced surface receptor loss by ELISA (Mundell et al., 2004). Stimulation with either ADP (10 $\mu$ M; 5 min) or PMA (1 $\mu \mathrm{M} ; 15 \mathrm{~min})$ induced internalization of both $\mathrm{P}_{2} \mathrm{Y}_{1}$ and $\mathrm{P}_{2} \mathrm{Y}_{12}$ receptors (Fig. 4). The rate of internalisation is shown in Fig. 4 A \& B for $\mathrm{P}_{2} \mathrm{Y}_{1}$ and $\mathrm{P} 2 \mathrm{Y}_{12}$ receptors respectively. Importantly also we show that carbachol $(1 \mathrm{mM})$, operating through endogenously expressed muscarinic $\mathrm{M}_{3}$ receptors, is able heterologously to induce internalisation of both $\mathrm{P} 2 \mathrm{Y}_{1}$ and $\mathrm{P} 2 \mathrm{Y}_{12}$ receptors. Pre-treatment with GF109203X (1 $\mu \mathrm{M} ; 15 \mathrm{~min})$ selectively attenuated ADP-induced $\mathrm{P}_{2} \mathrm{Y}_{1}$ receptor internalization whilst that of the P2Y 12 receptor was unaffected (Fig. 4C). As expected inhibition of PKC with GF109203X reversed internalisation of both $\mathrm{P}_{2} \mathrm{Y}_{1}$ and $\mathrm{P}_{2} \mathrm{Y}_{12}$ receptors induced by PMA. ADP and PMA-induced $\mathrm{P} 2 \mathrm{Y}_{1}$ receptor internalisation was partially inhibited by expression of either PKC $\alpha$ - or PKC $\delta$-DNM, with coexpression of both DNMs producing a more robust inhibition of receptor internalisation (Fig. 4D). As with GF109203X pre-treatment, expression of PKC $\alpha$ - or PKC $\delta$-DNM did not attenuate ADP-induced P2Y $\mathrm{Y}_{12}$ receptor internalisation (Fig. 4D). Interestingly, consistent with their effects upon functional desensitisation, expression of DNM-PKC $\delta$ but not DNM-PKC $\alpha$ attenuated PMA-induced $\mathrm{P} 2 \mathrm{Y}_{12}$ receptor internalisation (Fig. 4D).

Regulation of $P 2 Y_{1}$ and $P 2 Y_{12}$ receptor desensitisation by $P K C$ in human platelets - Since our studies in $1321 \mathrm{~N} 1$ cells revealed that $\mathrm{PKC}$ could regulate $\mathrm{P} 2 \mathrm{Y}_{1}$ and $\mathrm{P} 2 \mathrm{Y}_{12}$ receptor function we sought to determine if this was also the case in human platelets. Recently we reported that, in response to ADP, PKC can regulate the desensitisation of $\mathrm{P}_{2} \mathrm{Y}_{1}$ purinergic receptor responses in human platelets (Hardy et al., 2005). Therefore as expected pre-treatment with PMA resulted in a significant reduction in subsequent ADPpromoted $\mathrm{P}_{2} \mathrm{Y}_{1}$ receptor-mediated calcium response (Fig. 5A). Inhibition of PKC with GF109203X (2 $\mu \mathrm{M})$, a non-selective $\mathrm{PKC}$ inhibitor significantly attenuated $\mathrm{P}_{2} \mathrm{Y}_{1}$ receptor desensitisation. Pre-treatment with Gö6976 (1 $\mu \mathrm{M})$, which inhibits calcium-dependent classical PKC isoforms (Martiny-Baron et al., 
Molecular Pharmacology Fast Forward. Published on June 27, 2006 as DOI: 10.1124/mol.106.023549

This article has not been copyedited and formatted. The final version may differ from this version.

$\operatorname{MOL}(2006 / 023549)$

1993), including PKC $\alpha$, and rottlerin $(10 \mu \mathrm{M})$, a $\mathrm{PKC} \delta$ isoform selective inhibitor (Gschwendt et al., 1994), were unable to attenuate PMA promoted $\mathrm{P}_{2} \mathrm{Y}_{1}$-receptor desensitisation (Fig. 5A). Importantly however, pre-treatment with both Gö6976 and rottlerin was able to partially attenuate the desensitisation of $\mathrm{P}_{2} \mathrm{Y}_{1}$ receptor activity. Stimulation of PKC with PMA also decreased ADP-induced $\mathrm{P}_{2} \mathrm{Y}_{12}$ receptormediated inhibition of forskolin stimulated adenylyl cyclase (Fig. 5B(i) shows actual numbers and Fig. 5B(ii) shows normalised data) to a level comparable to that induced by ADP pre-treatment (Hardy et al., 2005). Pre-treatment with either GF109203X or rottlerin attenuated PMA-induced P2 $\mathrm{Y}_{12}$ receptor desensitisation whilst Gö6976 had no effect on desensitisation of the $\mathrm{P} 2 \mathrm{Y}_{12}$ response (Fig. 5B). Therefore stimulation of PKC activity can promote the heterologous desensitisation of both $\mathrm{P} 2 \mathrm{Y}_{1}$ and $\mathrm{P} 2 \mathrm{Y}_{12}$ receptor responses in human platelets. Finally, in order to demonstrate that, in the platelet system the Gq-coupled $\mathrm{P} 2 \mathrm{Y}_{1}$ receptor may regulate $\mathrm{P} 2 \mathrm{Y}_{12}$, we chose to investigate the effect of $\mathrm{P} 2 \mathrm{Y}_{1}$ receptor blockade upon ADP-induced desensitisation of the $\mathrm{P}_{2} \mathrm{Y}_{12}$ receptor response. Figure 6 shows that pre-treatment of platelets with the $\mathrm{P}_{2} \mathrm{Y}_{1}$ receptor antagonist A3P5P $(1 \mathrm{mM})$ does not attenuate $\mathrm{P} 2 \mathrm{Y}_{12}$-mediated inhibition of adenylyl cyclase, but that in the presence of A3P5P the ADP-induced desensitisation of the P2 $\mathrm{Y}_{12}$ receptor is reduced, indicating partial heterologous regulation of $\mathrm{P} 2 \mathrm{Y}_{12}$ by the $\mathrm{P} 2 \mathrm{Y}_{1}$ receptor.

Internalization of $P 2 Y_{1}$ and $P 2 Y_{12}$ receptors in human platelets - In order to study the internalization of purinergic receptors in human platelets we made use of the non-specific P2 ligand 2MeSADP (Takasaki et al., 2001). Importantly we chose to use formaldehyde-fixed platelets for our study. The reason for doing so was to be able to avoid complications to the binding assay produced by released ADP and ATP, which would compete with radioligand for binding sites. This has been a problem in other studies, and the use of fixed platelets to overcome this problem has been validated previously (Agarwal et al., 1989; Jefferson et al., 1988). Saturation binding experiments measuring $\left[{ }^{3} \mathrm{H}\right]-2 \mathrm{MeSADP}$ binding to fixed platelets in the presence and absence of unlabelled radioligand $(10 \mu \mathrm{M})$ indicated that there were $901 \pm 41\left[{ }^{3} \mathrm{H}\right]$ 2MeSADP binding sites per platelet with an affinity of $4.9 \pm 0.3 \mathrm{nM}$. Further saturation experiments using the $\mathrm{P}_{2} \mathrm{Y}_{1}$ receptor antagonist A3P5P $(1 \mathrm{mM})$ or the $\mathrm{P}_{12} \mathrm{Y}_{12}$ receptor antagonist AR-C69931MX (1 
Molecular Pharmacology Fast Forward. Published on June 27, 2006 as DOI: 10.1124/mol.106.023549

This article has not been copyedited and formatted. The final version may differ from this version.

$\operatorname{MOL}(2006 / 023549)$

$\mu \mathrm{M})$ revealed two distinct binding populations of $184 \pm 27$ and $644 \pm 11\left[{ }^{3} \mathrm{H}\right]-2 \mathrm{MeSADP}$ binding sites per platelet, which represent the $\mathrm{P} 2 \mathrm{Y}_{1}$ and $\mathrm{P} 2 \mathrm{Y}_{12}$ receptors respectively. Interestingly experiments using combined $\mathrm{P} 2 \mathrm{Y}_{1}$ and $\mathrm{P} 2 \mathrm{Y}_{12}$ receptor antagonists estimated the number of binding sites to be $844 \pm 57$, a number not significantly different to that obtained with unlabelled 2MeSADP. Further experiments using a fixed concentration of $\left[{ }^{3} \mathrm{H}\right]-2 \mathrm{MeSADP}(100 \mathrm{nM})$ revealed that the concentrations of A3P5P and ARC69931MX used in the saturation analysis studies were indeed maximal (data not shown), and that the respective $\mathrm{IC}_{50} \mathrm{~s}$ for these antagonists were determined to be $19.9 \pm 1.2 \mathrm{mM}$ and $45.0 \pm 2.4 \mathrm{nM}$, values which correlate well with those reported by Takasaki et al. (Takasaki et al., 2001).

Therefore in subsequent experiments (Fig. 7) examining receptor internalization, platelets were incubated with $\left[{ }^{3} \mathrm{H}\right]-2 \mathrm{MeSADP}(100 \mathrm{nM})$ in the presence of A3P5P $(1 \mathrm{mM})$ or AR-C69931MX $(1 \mu \mathrm{M})$ to give an estimate of either the $\mathrm{P} 2 \mathrm{Y}_{1}$ or $\mathrm{P}_{2} \mathrm{Y}_{12}$ surface binding sites. Following pre-treatment with ADP $(10 \mu \mathrm{M} ; 10$ min), its subsequent removal with apyrase $(0.2$ unit $/ \mathrm{ml} ; 3 \mathrm{~min})$ and platelet fixation, there was a clear reduction in $\left[{ }^{3} \mathrm{H}\right]-2 \mathrm{MeSADP}$ binding to both $\mathrm{P} 2 \mathrm{Y}_{1}$ and $\mathrm{P} 2 \mathrm{Y}_{12}$ receptors compared with non-pretreated or apyrase alone treated controls (Fig. 7A). Further studies showed that the $\mathrm{P} 2 \mathrm{Y}_{12}$ receptor internalised much more rapidly than the $\mathrm{P}_{2} \mathrm{Y}_{1}$ receptor although by 30 minutes the relative surface expression of each receptor was comparable (Fig. 7B). Therefore, as in $1321 \mathrm{~N} 1$ cells, both the $\mathrm{P} 2 \mathrm{Y}_{1}$ and $\mathrm{P} 2 \mathrm{Y}_{12}$ purinergic receptors internalise in a rapid agonist-dependent manner in human platelets.

$P K C$-dependent regulation of $P 2 Y_{1}$ and $P 2 Y_{12}$ receptor surface receptor expression and internalization in human platelets - In order to address the role PKC may play in this process we used the PKC inhibitors, GF109203X, Gö6976 and rottlerin described above. Interestingly pre-treatment of platelets with any of these inhibitors significantly increased the number of $\mathrm{P}_{2} \mathrm{Y}_{1}$ binding sites, with GF109203X the most potent (Fig. 7C). Pre-treatment with GF109203X or rottlerin also significantly increased the number of P2 $\mathrm{Y}_{12}$ receptor binding sites whilst Gö6976 had no significant effect (Fig. 7C). Inhibition of PKC activity with GF109203X, rottlerin or Gö6976 selectively attenuated ADP $\left(10 \mu \mathrm{M} ; 5\right.$ min)-induced P2 $\mathrm{Y}_{1}$ receptor 
Molecular Pharmacology Fast Forward. Published on June 27, 2006 as DOI: 10.1124/mol.106.023549

This article has not been copyedited and formatted. The final version may differ from this version.

$\operatorname{MOL}(2006 / 023549)$

internalisation whilst that of the $\mathrm{P} 2 \mathrm{Y}_{12}$ was unaffected (Fig. 7D) in agreement with our studies in 1321N1 cells (Fig. 4C). Stimulation of platelets with PMA (1 $\mu \mathrm{M} ; 15 \mathrm{~min})$ significantly enhanced the internalisation of both the $\mathrm{P}_{2} \mathrm{Y}_{1}$ and $\mathrm{P} 2 \mathrm{Y}_{12}$ receptor (Fig. 7D). Pre-treatment with each of the $\mathrm{PKC}$ inhibitors reduced PMA-promoted $\mathrm{P}_{2} \mathrm{Y}_{1}$ receptor internalisation. Again only GF109203X or rottlerin significantly reduced PMA-promoted $\mathrm{P}_{2} \mathrm{Y}_{12}$ surface receptor loss. Therefore, PKC can regulate the surface expression and internalisation of both $\mathrm{P} 2 \mathrm{Y}_{1}$ and $\mathrm{P} 2 \mathrm{Y}_{12}$ receptors in human platelets. 
Molecular Pharmacology Fast Forward. Published on June 27, 2006 as DOI: 10.1124/mol.106.023549

This article has not been copyedited and formatted. The final version may differ from this version.

$\operatorname{MOL}(2006 / 023549)$

\section{DISCUSSION}

The activation of $\mathrm{P} 2 \mathrm{Y}_{1}$ and $\mathrm{P} 2 \mathrm{Y}_{12}$ purinergic receptors by ADP is critical for normal platelet function. In order to avoid inappropriate thrombosis the sensitivity of these receptors to agonist needs to be continuously regulated. To date, the molecular mechanisms regulating platelet $\mathrm{P} 2 \mathrm{Y}_{1}$ and $\mathrm{P} 2 \mathrm{Y}_{12}$ purinergic receptor signalling and surface receptor expression are relatively poorly understood. In this study investigating the regulation of these two clinically important GPCRs we find both are phosphorylated following activation of PKC and demonstrate that their surface expression and activity are tightly regulated by this family of kinases. We show that specific PKC isoforms can differentially regulate $\mathrm{P} 2 \mathrm{Y}_{1}$ and $\mathrm{P} 2 \mathrm{Y}_{12}$ receptor function, demonstrating some redundancy of $\mathrm{PKC}$ isoforms for regulation of $\mathrm{P} 2 \mathrm{Y}_{1}$ but lack of redundancy of $\mathrm{PKC}$ isoforms for regulation of $\mathrm{P}_{2} \mathrm{Y}_{12}$, which is heterologously controlled by $\mathrm{PKC} \delta$. Although $\mathrm{P}_{2} \mathrm{Y}_{1}$ and $\mathrm{P} 2 \mathrm{Y}_{12}$ purinergic receptors play an essential role in ADP-induced platelet activation and are important pharmacological targets in the treatment of arterial thrombotic disease (Foster et al., 2001; Gachet, 2005; Kunapuli et al., 2003) minimal studies have investigated the regulation of function of these two GPCRs. In a recent study (Hardy et al., 2005) we demonstrated for the first time that both P2 $\mathrm{Y}_{1}$ and $\mathrm{P} 2 \mathrm{Y}_{12}$ receptors desensitise in platelets and show that these receptors desensitise by different kinasedependent mechanisms, where GRKs regulate the $\mathrm{P}_{2} \mathrm{Y}_{12}$ receptor and $\mathrm{PKC}$ regulates agonist-induced desensitization of the $\mathrm{P}_{2} \mathrm{Y}_{1}$ receptor in human platelets. Protein kinase $\mathrm{C}$ has been shown also to phosphorylate and regulate agonist-unoccupied receptors (Hipkin et al., 2000; Mundell et al., 2002; Xiang et al., 2001). Initially we demonstrated that both $\mathrm{P}_{2} \mathrm{Y}_{1}$ and $\mathrm{P} 2 \mathrm{Y}_{12}$ receptors underwent ADP-induced phosphorylation and that activation of PKC by PMA also promoted phosphorylation of both receptor subtypes. To our knowledge this is the first demonstration that either of these GPCRs can be phosphorylated in an agonist-dependent or independent manner. The non-selective PKC inhibitor GF109203X attenuated ADP-stimulated $\mathrm{P} \mathrm{Y}_{1}$ receptor phosphorylation consistent with our recent demonstration that PKC regulates agonist-induced $\mathrm{P}_{2} \mathrm{Y}_{1}$ receptor activity (Hardy et al., 2005). Although PKC can activate GRK2 and 3 isoforms, promoting their translocation to the cell membrane (Winstel et 
Molecular Pharmacology Fast Forward. Published on June 27, 2006 as DOI: 10.1124/mol.106.023549

This article has not been copyedited and formatted. The final version may differ from this version.

$\operatorname{MOL}(2006 / 023549)$

al., 1996), these kinases are unlikely to mediate agonist-independent PMA-dependent phosphorylation since GRKs only phosphorylate agonist-occupied receptors (Penn et al., 2000; Pitcher et al., 1998). We would therefore propose, from the present data, that PKC isoforms lie directly upstream of phosphorylation of $\mathrm{P} 2 \mathrm{Y}_{1}$ and $\mathrm{P} 2 \mathrm{Y}_{12}$ receptors, at least in $1321 \mathrm{~N} 1$ cells. These experiments were undertaken in P2Y receptor null 1321N1 cells stably expressing epitope tagged versions of both receptors. The lack of specific and high affinity P2Y receptor antibodies with which to isolate either receptor from platelet cell membranes prevents similar studies in human platelets at this time. There are however a number of putative PKC phosphorylation sites located within the C-terminus of both receptors, including $\mathrm{Thr}^{339}$ in the $\mathrm{P}_{2} \mathrm{Y}_{1}$ receptor, which regulates PKC-dependent desensitisation (Fam et al., 2003), and may be important as such in platelets.

Since phosphorylation of agonist-unoccupied receptors has been implicated in desensitisation and internalization of many GPCRs we sought to determine its functional significance and to identify the specific PKC isoforms responsible. Interestingly, PMA pre-treatment attenuated subsequent ADPstimulated $\mathrm{P} 2 \mathrm{Y}_{1}$ and $\mathrm{P} 2 \mathrm{Y}_{12}$ receptor activity and promoted agonist-independent surface receptor loss, the first demonstration of heterologous regulation of these GPCRs. Over-expression of dominant negative mutant (DNM) catalytically inactive forms of $\mathrm{PKC} \alpha$ and $\mathrm{PKC} \delta$, the two $\mathrm{PKC}$ isoforms common to both platelets and $1321 \mathrm{~N} 1$ cells, revealed that both isoforms regulated the agonist and PMA-induced desensitisation and internalization of $\mathrm{P}_{2} \mathrm{Y}_{1}$ receptors since an attenuation of receptor desensitisation and surface receptor loss was only evident on co-expression of both DNMs. ADP-induced P2 $\mathrm{Y}_{12}$ receptor desensitisation is regulated by GRKs and for this receptor we have ruled out any contribution from PKCs since expression of DNM PKC constructs did not have any effect (Hardy et al., 2005). Interestingly, however, we found that heterologous PMA-promoted desensitisation and internalization of $\mathrm{P} 2 \mathrm{Y}_{12}$ receptor function was regulated by $\mathrm{PKC} \delta$ alone. Importantly also we now show that not only receptor-independent activation of $\mathrm{PKC}$, but also activation of $\mathrm{PKC}$ by endogenous $\mathrm{M}_{3}$ muscarinic receptors in $1321 \mathrm{~N} 1$ cells is able to induce internalisation of both $\mathrm{P}_{2} \mathrm{Y}_{1}$ and $\mathrm{P} 2 \mathrm{Y}_{12}$ receptors (Fig. 4A\&B). Collectively these novel findings in $1321 \mathrm{~N} 1$ cells demonstrate that PKC-dependent phosphorylation of both $\mathrm{P}_{2} \mathrm{Y}_{1}$ and $\mathrm{P}_{2} \mathrm{Y}_{12}$ 
Molecular Pharmacology Fast Forward. Published on June 27, 2006 as DOI: 10.1124/mol.106.023549

This article has not been copyedited and formatted. The final version may differ from this version.

$\operatorname{MOL}(2006 / 023549)$

receptors can significantly decrease receptor function and promote a rapid loss of surface receptor. It is unclear at this time whether PMA-promoted loss of surface receptor plays a significant role in reduced receptor responsiveness or if PMA-stimulated receptor phosphorylation can lead to direct receptor / G protein uncoupling. Detailed studies investigating which regions of these GPCRs regulate their internalization are planned. Such studies will allow us to make internalization deficient receptor mutants and thereby determine if surface receptor loss plays a significant role in reduced signalling output.

As $\mathrm{PKC}$ heterologously regulates $\mathrm{P}_{2} \mathrm{Y}_{1}$ and $\mathrm{P}_{2} \mathrm{Y}_{12}$ receptor function and trafficking in $1321 \mathrm{~N} 1$ cells we next examined these phenomena in human platelets. Interestingly, as in $1321 \mathrm{~N} 1$ cells heterologous activation of $\mathrm{PKC}$ reduced subsequent $\mathrm{P} 2 \mathrm{Y}_{1}$ and $\mathrm{P} 2 \mathrm{Y}_{12}$ receptor responsiveness. Also importantly we showed in Fig. 6 that in platelets $\mathrm{P}_{2} \mathrm{Y}_{1}$ receptors contribute partially to desensitisation of $\mathrm{P} 2 \mathrm{Y}_{12}$ receptors in a heterologous manner. Since platelets lack a nucleus and significant protein synthetic machinery, approaches to disrupt or reduce endogenous protein function e.g. expression of dominant negative mutants are not viable at present. Therefore in order to determine the PKC isoforms that regulate purinergic receptor function we used three PKC inhibitors, GF109203X $(2 \mu \mathrm{M})$, a potent inhibitor of conventional and novel PKC isoforms (Toullec et al., 1991), Gö6976 (1 $\mu \mathrm{M})$, an inhibitor with $\mathrm{IC}_{50} \mathrm{~s}$ in the nanomolar range for calcium-dependent PKC isoforms (Martiny-Baron et al., 1993), including PKC $\alpha$, and rottlerin $(10 \mu \mathrm{M})$ which selectively inhibits the calcium-independent $\mathrm{PKC}$ isoforms, inhibiting $\mathrm{PKC} \delta$ with an $\mathrm{IC}_{50}$ of approximately $5 \mu \mathrm{M} ; 10-30$ fold higher concentrations are required to inhibit conventional PKC isoforms (Gschwendt et al., 1994). Using these selective inhibitors we found that as in 1321N1 cells, classical and novel isoforms of $\mathrm{PKC}$ can regulate the heterologous desensitisation of $\mathrm{P}_{2} \mathrm{Y}_{1}$ receptor activity whilst only $\mathrm{PKC} \delta$ was capable of desensitising $\mathrm{P}_{2} \mathrm{Y}_{12}$ receptor activity in an agonist-independent manner.

In order to examine changes in purinergic receptor surface expression in human platelets we used the P2Y receptor radioligand $\left[{ }^{3} \mathrm{H}\right]-2 \mathrm{MeSADP}$ in combination with the $\mathrm{P}_{2} \mathrm{Y}_{1}$ receptor antagonist $\mathrm{A} 3 \mathrm{P} 5 \mathrm{P}$ and the P2Y 12 receptor antagonist AR-C69931MX. Our estimates of receptor number (see Results section) are 
Molecular Pharmacology Fast Forward. Published on June 27, 2006 as DOI: 10.1124/mol.106.023549

This article has not been copyedited and formatted. The final version may differ from this version.

$\operatorname{MOL}(2006 / 023549)$

similar to those obtained by others (Baurand et al., 2000). This is important since we had chosen to use formaldehyde-fixed platelets for our study. In our study, following stimulation with ADP the number of binding sites for both $\mathrm{P} 2 \mathrm{Y}_{1}$ and $\mathrm{P} 2 \mathrm{Y}_{12}$ receptors was significantly reduced. Recent investigations, in agreement with our own, indicate that agonist pre-treatment with ADP $\beta S$ also reduced the number of P2Y $Y_{1}$ receptor binding sites in stably transfected 1321N1 cells (Baurand et al., 2000; Baurand et al., 2005). This was paralleled in the study of Baurand et al. (2005) by ADP-induced internalisation of P2 $\mathrm{Y}_{1}$ receptors in platelets. By contrast however, $\mathrm{P}_{2} \mathrm{Y}_{12}$ receptor surface expression was reported by these authors not to change following pre-treatment of $1321 \mathrm{~N} 1$ cells with ADP $\beta S$, and only to internalise transiently and very rapidly upon treatment of platelets with $5 \mu \mathrm{M}$ ADP. The data relating to the P2 $\mathrm{Y}_{12}$ receptor are therefore in contrast to those of the present study, where we show a more sustained internalisation in platelets and $1321 \mathrm{~N} 1$ cells. The reasons for the discrepancy between our data and those of Baurand et al. (2005) are not clear, although there are a number of methodological differences between the two studies. First, it should be noted that since ADP $\beta S$ is less potent at $\mathrm{P} 2 \mathrm{Y}_{12}$ receptors than $\mathrm{P} 2 \mathrm{Y}_{1}$ (Takasaki et al., 2001) and is a partial agonist at the $\mathrm{P}_{2} \mathrm{Y}_{12}$ purinergic receptor (Cusack and Hourani, 1981), it may be unable to promote full internalization of this receptor (Clark et al., 1999). Additionally, the study of Baurand et al. (2005) used GFP-tagged receptor expressed in 1321N1 cells (Baurand et al., 2005), in contrast to the HA tag used in our study. The relatively bulky GFP tag may unpredictably alter signalling and trafficking properties of the receptor. The platelet studies also differ in that Baurand et al. (2005) use an immunogold transmission electron microscopic approach whereas the present study uses a radioligand binding approach. These methodological differences may explain the different results obtained for $\mathrm{P}_{2} \mathrm{Y}_{12}$ receptors. Interestingly, in our study, pre-treatment with PMA also reduced $\mathrm{P} 2 \mathrm{Y}_{1}$ and $\mathrm{P} 2 \mathrm{Y}_{12}$ receptor surface expression. This is the first demonstration that heterologous activation of PKC can promote the internalisation of $\mathrm{P} 2 \mathrm{Y}$ receptors in human platelets.

Interestingly in the absence of agonist treatment the surface expression of both receptors was increased following pre-treatment with inhibitors of PKC (Fig. 7C) and it seems likely therefore that basal PKC 
Molecular Pharmacology Fast Forward. Published on June 27, 2006 as DOI: 10.1124/mol.106.023549

This article has not been copyedited and formatted. The final version may differ from this version.

$\operatorname{MOL}(2006 / 023549)$

activity is directly regulating surface receptor number. In $1321 \mathrm{~N} 1$ cells following agonist-induced internalization, both the $\mathrm{P} 2 \mathrm{Y}_{1}$ and $\mathrm{P} 2 \mathrm{Y}_{12}$ receptors can subsequently recycle to the cell surface (data not shown). It is therefore possible that an attenuation of agonist-independent receptor internalisation by inhibition of PKC, coupled with recycling of receptor already present in endocytic compartments back to the cell surface, together leads to increased cell surface receptor number.

As with heterologous receptor desensitisation in platelets, PMA-dependent $\mathrm{P}_{2} \mathrm{Y}_{1}$ receptor loss is regulated by both classical isoforms of $\mathrm{PKC}$ and $\mathrm{PKC} \delta$ whilst only $\mathrm{PKC} \delta$ regulates agonist-independent $\mathrm{P} 2 \mathrm{Y}_{12}$ receptor internalization. It is unclear why there is functional redundancy between PKC $\alpha$ and PKC $\delta$ in their ability to regulate $\mathrm{P}_{2} \mathrm{Y}_{1}$ receptor function in human platelets. These two isoforms play different roles in platelet function (Crosby and Poole, 2003; Murugappan et al., 2005; Murugappan et al., 2004; Pula et al., 2005) and their different modes of activation may in turn determine their ability to phosphorylate downstream targets. It is also unclear why $\mathrm{PKC} \delta$ specifically attenuates $\mathrm{P}_{2} \mathrm{Y}_{12}$ receptor signalling. The activity of PKC isoforms is tightly regulated by multiple molecular mechanisms including interaction with binding-partner proteins (Poole et al., 2004). A greater understanding of the protein-protein interactions between particular PKC isoforms and membrane-associated anchoring protein, which serve to recruit the PKC isoforms to distinct subcellular compartments, in close proximity to receptor target substrates should prove useful in unravelling patterns of GPCR / PKC isoform specificity.

In conclusion, since ADP performs a pivotal role in the formation of stable platelet aggregates, the activity of purinergic receptors may maintain the delicate balance between rest and activation that underlies platelet sensitivity. Our results show for the first time that regulation of platelet purinergic receptor expression and activity by specific PKC isoforms may play a significant role in haemostatic function. 
Molecular Pharmacology Fast Forward. Published on June 27, 2006 as DOI: 10.1124/mol.106.023549

This article has not been copyedited and formatted. The final version may differ from this version.

$\operatorname{MOL}(2006 / 023549)$

\section{ACKNOWLEDGEMENTS}

We are grateful to Professors Motoi Ohba (Showa University, Shinagawa, Tokyo, Japan) and Toshio Kuroki (Gifu University, Gifu, Japan) for generation of PKC DNMs in adenovirus and to Professor David Murphy (University of Bristol, UK) for supply of these viruses. The authors would also like to thank AstraZeneca for the generous supply of AR-C69931MX. 
Molecular Pharmacology Fast Forward. Published on June 27, 2006 as DOI: 10.1124/mol.106.023549

This article has not been copyedited and formatted. The final version may differ from this version.

$\operatorname{MOL}(2006 / 023549)$

\section{REFERENCES}

Agarwal AK, Tandon NN, Greco NJ, Cusack NJ and Jamieson GA (1989) Evaluation of the binding to fixed platelets of agonists and antagonists of ADP-induced aggregation. Thromb. Haemost. 62:1103-1106.

Baurand A, Eckly A, Bari N, Leon C, Hechler B, Cazenave JP and Gachet C (2000) Desensitization of the platelet aggregation response to ADP: differential down-regulation of the $\mathrm{P} 2 \mathrm{Y}_{1}$ and $\mathrm{P} 2_{\mathrm{cyc}}$ receptors. Thromb. Haemost. 84:484-491.

Baurand A, Eckly A, Hechler B, Kauffenstein G, Galzi JL, Cazenave JP, Leon C and Gachet C (2005) Differential regulation and relocalization of the platelet $\mathrm{P} 2 \mathrm{Y}$ receptors after activation: a way to avoid loss of hemostatic properties? Mol Pharmacol 67:721-33.

Blass M, Kronfeld I, Kazimirsky G, Blumberg PM and Brodie C (2002) Tyrosine phosphorylation of protein kinase Cdelta is essential for its apoptotic effect in response to etoposide. Mol Cell Biol 22:182-95.

Buensuceso CS, Obergfell A, Soriani A, Eto K, Kiosses WB, Arias-Salgado EG, Kawakami T and Shattil SJ (2005) Regulation of Outside-in Signaling in Platelets by Integrin-associated Protein Kinase C\{beta\}. J. Biol. Chem. 280:644-653.

Clark RB, Knoll BJ, Barber R, Cusack NJ and Hourani SM (1999) Partial agonists and G protein-coupled receptor desensitization. Trends Pharmacol Sci 20:279-86.

Crosby D and Poole AW (2002) Interaction of Bruton's tyrosine kinase and protein kinase Ctheta in platelets. Cross-talk between tyrosine and serine/threonine kinases. J Biol Chem 277:9958-65.

Crosby D and Poole AW (2003) Physical and functional interaction between PKC $\delta$ and Fyn tyrosine kinase in human platelets. J Biol Chem 278:24533-24541.

Cusack NJ and Hourani SM (1981) Partial agonist behaviour of adenosine 5'-O-(2-thiodiphosphate) on human platelets. Br J Pharmacol 73:405-8.

Daunt DA, Hurt C, Hein L, Kallio J, Feng F and Kobilka BK (1997) Subtype-specific intracellular trafficking of alpha2-adrenergic receptors. Mol Pharmacol 51:711-20. 
Molecular Pharmacology Fast Forward. Published on June 27, 2006 as DOI: 10.1124/mol.106.023549

This article has not been copyedited and formatted. The final version may differ from this version.

$\operatorname{MOL}(2006 / 023549)$

Fam SR, Gallagher CJ, Kalia LV and Salter MW (2003) Differential frequency dependence of P2Y1- and P2Y2- mediated Ca 2+ signaling in astrocytes. J Neurosci 23:4437-44.

Ferguson SSG (2001) Evolving concepts in G protein-coupled receptor endocytosis: The role in receptor desensitisation and signalling. Pharmacol Rev 53:1-24.

Foster CJ, Prosser DM, Agans JM, Zhai Y, Smith MD, Lachowicz JE, Zhang FL, Gustafson E, Monsma FJJ, Wiekowski MT, Abbondanzo SJ, Cook DN, Bayne ML, Lira SA and Chintala MS (2001) Molecular identification and characterization of the platelet ADP receptor targeted by thienopyridine antithrombotic drugs. J. Clin. Invest. 107:1591-1598.

Gachet C (2005) Regulation of Platelet Functions by P2 Receptors. Annu Rev Pharmacol Toxicol 21:21.

Grynkiewicz G, Poenie M and Tsien RY (1985) A new generation of Ca2+ indicators with greatly improved fluorescence properties. J Biol Chem 260:3440-50.

Gschwendt M, Muller HJ, Kielbassa K, Zang R, Kittstein W, Rincke G and Marks F (1994) Rottlerin, a novel protein kinase inhibitor. Biochem Biophys Res Commun 199:93-8.

Hardy AR, Conley PB, Luo J, Benovic JL, Poole AW and Mundell SJ (2005) P2Y1 and P2Y12 receptors for ADP desensitize by distinct kinase-dependent mechanisms. Blood 105:3552-60.

Hipkin RW, Wang Y and Schonbrunn A (2000) Protein kinase C activation stimulates the phosphorylation and internalization of the sst2A somatostatin receptor. J Biol Chem 275:5591-9.

Jefferson J, Harmon J and Jamieson G (1988) Identification of high-affinity (Kd 0.35 mumol/L) and lowaffinity (Kd 7.9 mumol/L) platelet binding sites for ADP and competition by ADP analogues. Blood 71:110-116.

Kanegae Y, Makimura M and Saito I (1994) A simple and efficient method for purification of infectious recombinant adenovirus. Jpn J Med Sci Biol 47:157-166.

Kunapuli SP, Ding Z, Dorsam RT, Kim S, Murugappan S and Quinton TM (2003) ADP receptors--targets for developing antithrombotic agents. Curr Pharm Des 9:2303-16. 
Molecular Pharmacology Fast Forward. Published on June 27, 2006 as DOI: 10.1124/mol.106.023549

This article has not been copyedited and formatted. The final version may differ from this version.

$\operatorname{MOL}(2006 / 023549)$

Martiny-Baron G, Kazanietz MG, Mischak H, Blumberg PM, Kochs G, Hug H, Marme D and Schachtele C (1993) Selective inhibition of protein kinase C isozymes by the indolocarbazole Go 6976. J Biol Chem 268:9194-7.

Mitsutake N, Namba H, Shklyaev SS, Tsukazaki T, Ohtsuru A, Ohba M, Kuroki T, Ayabe H and Yamashita S (2001) PKC delta mediates ionizing radiation-induced activation of c-Jun NH(2)terminal kinase through MKK7 in human thyroid cells. Oncogene 20:989-996.

Moran-Jimenez M-J and Matute C (2000) Immunohistochemical localization of the P2Y1 purinergic receptor in neurons and glial cells of the central nervous system. Molecular Brain Research 78:50-58.

Mundell SJ, Benovic JL and Kelly E (1997) Selective inhibition of adenosine A2 receptor desensitization in NG108-15 cells stably transfected with Dominant Negative Mutant GRK2. Mol. Pharmacol. 51:991-998.

Mundell SJ, Matharu AL, Kelly E and Benovic JL (2000) Arrestin isoforms dictate differential kinetics of A2B adenosine receptor trafficking. Biochemistry 39:12828-12836.

Mundell SJ, Matharu AL, Pula G, Holman D, Roberts PJ and Kelly E (2002) Metabotropic Glutamate receptor 1 internalization induced by muscarinic acetylcholine receptor activation: Differential dependency of internalization of splice variants on non-visual arrestins. Mol. Pharmacol. 61:1114-1123.

Mundell SJ, Pula G, More JC, Jane DE, Roberts PJ and Kelly E (2004) Activation of cyclic AMPdependent protein kinase inhibits the desensitization and internalization of metabotropic glutamate receptors 1a and 1b. Mol Pharmacol 65:1507-16.

Murugappan S, Shankar H, Bhamidipati S, Dorsam RT, Jin J and Kunapuli SP (2005) Molecular mechanism and functional implications of thrombin-mediated tyrosine phosphorylation of PKCdelta in platelets. Blood 106:550-557. 
Molecular Pharmacology Fast Forward. Published on June 27, 2006 as DOI: 10.1124/mol.106.023549

This article has not been copyedited and formatted. The final version may differ from this version.

$\operatorname{MOL}(2006 / 023549)$

Murugappan S, Tuluc F, Dorsam RT, Shankar H and Kunapuli SP (2004) Differential role of protein kinase $\mathrm{C}$ delta isoform in agonist-induced dense granule secretion in human platelets. J Biol Chem 279:2360-2367.

Ohba M, Ishino K, Kashiwagi M, Kawabe S, Chida K, Huh NH and Kuroki T (1998) Induction of differentiation in normal human keratinocytes by adenovirus-mediated introduction of the eta and delta isoforms of protein kinase C. Mol Cell Biol 18:5199-5207.

Penn RB, Pronin AN and Benovic JL (2000) Regulation of G protein-coupled receptor kinases. Trends Cardiovasc Med 10:81-9.

Pitcher JA, Freedman NJ and Lefkowitz RJ (1998) G protein-coupled receptor kinases. Annu. Rev. Biochem. 67:653-692.

Poole AW, Heath MF and Evans RJ (1993) ADP induces desensitisation of equine platelet aggregation responses: studies using ADP beta S, a stable analogue of ADP. Res Vet Sci 54:235-43.

Poole AW, Pula G, Hers I, Crosby D and Jones ML (2004) PKC-interacting proteins: from function to pharmacology. Trends Pharmacol Sci 25:528-535.

Poole AW, Watson SP, Heath MF and Evans RJ (1995) Regulation of cytosolic calcium by collagen in single human platelets. Br J Pharmacol 115:101-6.

Pula G, Crosby D, Baker J and Poole AW (2005) Functional interaction of protein kinase Calpha with the tyrosine kinases Syk and Src in human platelets. J Biol Chem 280:7194-7205.

Takasaki J, Kamohara M, Saito T, Matsumoto M, Matsumoto S, Ohishi T, Soga T, Matsushime H and Furuichi K (2001) Molecular cloning of the platelet P2T(AC) ADP receptor: pharmacological comparison with another ADP receptor, the P2Y(1) receptor. Mol. Pharmacol. 60:432-439.

Toullec D, Pianetti P, Coste H, Bellevergue P, Grand-Perret T, Ajakane M, Baudet V, Boissin P, Boursier E, Loriolle F and et al. (1991) The bisindolylmaleimide GF 109203X is a potent and selective inhibitor of protein kinase C. J Biol Chem 266:15771-81.

von Zastrow M (2003) Mechanisms regulating membrane trafficking of G protein-coupled receptors in the endocytic pathway. Life Sci 74:217-24. 
Molecular Pharmacology Fast Forward. Published on June 27, 2006 as DOI: 10.1124/mol.106.023549

This article has not been copyedited and formatted. The final version may differ from this version.

$\operatorname{MOL}(2006 / 023549)$

Winstel R, Freund S, Krasel C, Hoppe E and Lohse MJ (1996) Protein kinase cross-talk: membrane targeting of the beta-adrenergic receptor kinase by protein kinase C. Proc Natl Acad Sci U S A 93:2105-9.

Xiang B, Yu GH, Guo J, Chen L, Hu W, Pei G and Ma L (2001) Heterologous activation of protein kinase C stimulates phosphorylation of delta-opioid receptor at serine 344 , resulting in beta-arrestin- and clathrin-mediated receptor internalization. J Biol Chem 276:4709-4716.

Zhang XA, Bontrager AL and Hemler ME (2001) Transmembrane-4 superfamily proteins associate with activated protein kinase $\mathrm{C}(\mathrm{PKC})$ and link PKC to specific beta(1) integrins. J Biol Chem 276:25005-13. Epub 2001 Apr 26.

Zhong X, Kriz R, Seehra J and Kumar R (2004) N-linked glycosylation of platelet P2Y12 ADP receptor is essential for signal transduction but not for ligand binding or cell surface expression. FEBS

Letters 562:111-117. 


\section{FOOTNOTES}

ARH was supported by an A.J. Clark Studentship from the British Pharmacological Society. JFB is supported by a studentship from the British Heart Foundation (grant no. FS/04/023). The work was supported by programme and project grants from the British Heart Foundation (grant nos. PG/04/097/17620 \& RG/05/015) and the Wellcome Trust (grant nos. 064785 \& 069572). SJM holds a British Heart Foundation Basic Science Lectureship.

Address correspondence and reprint enquiries to: Alastair W. Poole, Department of Pharmacology, School of Medical Sciences, University Walk, Bristol, BS8 1TD, United Kingdom. Tel.: + 441179287635. FAX: + 44117925 0168. email: a.poole@bris.ac.uk. 


\section{FIGURE LEGENDS}

Figure 1. Protein kinase C-mediated phosphorylation of HA-P2Y $\mathrm{Y}_{1}$ and $\mathrm{HA}-\mathrm{P2} \mathrm{Y}_{12} \cdot{ }^{32} \mathrm{P}$-labelled 1321N1 human astrocytoma cells stably expressing either HA-P2Y 1 (A), HA-P2Y $\mathrm{Y}_{12}$ (B) or vector alone (pcNEO) were pretreated for 10 min with vehicle or $1 \mu \mathrm{M}$ GF109203X before the addition of the PKC activator phorbol 12-myristate 13-acetate (PMA; $1 \mu \mathrm{M} ; 15 \mathrm{~min})$, ADP (10 $\mu \mathrm{M} ; 5 \mathrm{~min}$ ) or vehicle alone. Phospho-HA-purinergic receptors were immunoprecipitated from membrane lysates and run on SDSPAGE before transfer to nitrocellulose membranes. Specific phosphorylated bands at (A) $45 \mathrm{kDa}\left(\mathrm{P}_{2} \mathrm{Y}_{1}\right)$ or $(\mathbf{B}) 70 \mathrm{kDa}\left(\mathrm{P} 2 \mathrm{Y}_{12}\right)$ not present in vector alone pcNEO transfected controls were subsequently identified by autoradiography. Similar amounts of receptor immunoprecipitation were confirmed (right hand panels (A) and (B)) by reprobing membranes with a polyclonal anti-HA antibody / horse radish peroxidase-conjugated antirabbit IgG and visualization by enhanced chemiluminescence (ECL).

Figure 2. PKC isoform expression in 1321N1 cells and human platelets. (A) Whole cell lysates from $1321 \mathrm{~N} 1$ cells and human platelets were subjected to SDS-PAGE, followed by immunoblotting with PKCisoform specific antibodies as detailed in "Materials and Methods". Data shown are representative of three experiments. (B) $1321 \mathrm{~N} 1$ cells were infected with $\beta \mathrm{Gal}-\mathrm{PKC} \alpha-\mathrm{DNM}, \beta \mathrm{Gal}$-PKC $\delta$-DNM or $\beta \mathrm{Gal}$ adenovirus alone as control. Whole cell lysates from these cells were subjected to SDS-PAGE followed by immunoblotting with PKC-isoform specific antibodies as detailed in "Materials and Methods". Bands therefore represent the sum of native wild type and heterologously expressed DNM-PKC. Data shown are representative of three experiments.

Figure 3. PKC-mediated desensitisation of $\mathrm{P}^{2} \mathrm{Y}_{1}$ and $\mathrm{P} 2 \mathrm{Y}_{12}$ purinergic receptor responses in $1321 \mathrm{~N} 1$ cells stably expressing each receptor. $1321 \mathrm{~N} 1$ astrocytoma cells were infected with $\beta \mathrm{Gal}-\mathrm{PKC} \alpha-\mathrm{DNM}$, $\beta G a l-P K C \delta$-DNM, both DNM constructs or $\beta$ Gal adenovirus alone (vector alone) as control. (A) 
Molecular Pharmacology Fast Forward. Published on June 27, 2006 as DOI: 10.1124/mol.106.023549

This article has not been copyedited and formatted. The final version may differ from this version.

$\operatorname{MOL}(2006 / 023549)$

Desensitization of $\mathrm{P}_{2} \mathrm{Y}_{1}$ receptors was assessed by comparing calcium responses to $\mathrm{ADP}(0.1 \mu \mathrm{M})$ before and after pre-treatment addition of $\operatorname{ADP}(1 \mu \mathrm{M} ; 2 \mathrm{~min})$ or PMA $(1 \mu \mathrm{M} ; 15 \mathrm{~min})$ as detailed in "Materials and Methods". Results are expressed as a \% of desensitisation of response and data are mean \pm S.E.M of at least three independent experiments. *Statistical significance at $\mathrm{p}<0.05$ for data compared with respective vector alone control (Mann-Whitney U-Test). (B) Agonist (ADP; $10 \mathrm{nM}$ )-dependent inhibition of forskolin $(1 \mu \mathrm{M} ; 10 \mathrm{~min})$-stimulated adenylyl cyclase activity by $\mathrm{P}_{2} \mathrm{Y}_{12}$ purinergic receptor activation after pre-treatment with ADP (10 $\mathrm{nM} ; 5 \mathrm{~min})$, PMA (1 $\mu \mathrm{M} ; 15 \mathrm{~min})$ or vehicle alone was subsequently determined. (B(i)) For vector alone control condition, data are presented as mean pmol cAMP $\mathrm{mg}^{-1} \mathrm{protein}$ \pm S.E.M. ( $\mathrm{n} \geq 4$ ). (B(ii)) For all conditions including vector alone control, normalised data are presented as mean \pm S.E.M of at least four independent experiments, expressed as $\%$ inhibition of forskolin-stimulated adenylyl cyclase. $*$ Statistical significance at $\mathrm{p}<0.05$ for data compared with respective non-pretreated agonist-induced inhibition of forskolin-stimulated controls (Mann-Whitney U-Test).

Figure 4. $\mathrm{PKC}$-mediated internalization of $\mathrm{P}_{2} \mathrm{Y}_{1}$ and $\mathrm{P} 2 \mathrm{Y}_{12}$ purinergic receptor responses in 1321N1 cells stably expressing each receptor.

(A) $\mathrm{P}_{2} \mathrm{Y}_{1}$ receptor- or (B) $\mathrm{P}_{2} \mathrm{Y}_{12}$ receptor-expressing $1321 \mathrm{~N} 1$ cells were challenged with $\mathrm{ADP}(10 \mu \mathrm{M})$, the protein kinase $\mathrm{C}$ activator PMA $(1 \mu \mathrm{M})$ or the muscarinic agonist carbachol $(1 \mathrm{mM})$. Surface receptor loss was assessed by ELISA at various time points after addition of agonist. Data represent mean \pm S.E.M. of five independent experiments. (C) $\mathrm{P}_{2} \mathrm{Y}_{1}$ or $\mathrm{P}_{2} \mathrm{Y}_{12}$ receptor-expressing $1321 \mathrm{~N} 1$ cells were pretreated with the PKC inhibitor GF109203X (1 $\mu \mathrm{M}$; $15 \mathrm{~min}$ ) and subsequently challenged with ADP (10 $\mu \mathrm{M}$; $30 \mathrm{~min})$ or the protein kinase $\mathrm{C}$ activator PMA $(1 \mu \mathrm{M}$; $30 \mathrm{~min})$. (D) $1321 \mathrm{~N} 1$ cells infected with $\beta \mathrm{Gal}$ PKC $\alpha$-DNM, $\beta$ Gal-PKC $\delta$-DNM, both DNM constructs or $\beta \mathrm{Gal}$ adenovirus alone as control, were subsequently challenged with ADP $(10 \mu \mathrm{M} ; 30 \mathrm{~min})$ or PMA (1 $\mu \mathrm{M} ; 30 \mathrm{~min})$. Surface receptor loss was assessed by ELISA. The data represent means \pm S.E.M. of five independent experiments. $* p<0.05$ compared to respective controls (Mann Whitney U-test). 
Molecular Pharmacology Fast Forward. Published on June 27, 2006 as DOI: 10.1124/mol.106.023549

This article has not been copyedited and formatted. The final version may differ from this version.

$\operatorname{MOL}(2006 / 023549)$

Figure 5. PKC-dependent desensitisation of purinergic receptor responses in human platelets. Platelets were pretreated for 15 minutes with either the non-specific PKC inhibitor GF109203X ( $\mu$ M), Gö6976 $(1 \mu \mathrm{M})$, which inhibits calcium-dependent PKC isoforms, including PKC $\alpha$, rottlerin $(10 \mu \mathrm{M})$, a PKC $\delta$ isoform selective inhibitor and subsequently challenged with PMA (1 $\mu \mathrm{M} ; 15$ min) or vehicle alone. (A) Desensitisation of $\mathrm{P}_{2} \mathrm{Y}_{1}$ purinergic receptor responses was assessed by comparing peak calcium responses to $10 \mu \mathrm{M}$ ADP in platelets treated with PMA versus vehicle alone. Values are mean \pm S.E.M. of three independent experiments and results are expressed as the ADP response after a desensitising dose of PMA as a percentage of the control response. ${ }^{*} \mathrm{p}<0.05$ for data compared with PMA treatment without PKC inhibitor (control; Mann Whitney U-test). (B) Platelets were either pretreated with PKC inhibitors (as described above) or with vehicle alone (control) as indicated. Agonist (ADP; $10 \mu \mathrm{M}$ )-dependent inhibition of forskolin ( $1 \mu \mathrm{M} ; 5 \mathrm{~min})$-stimulated adenylyl cyclase activity by $\mathrm{P}_{2} \mathrm{Y}_{12}$ purinergic receptor activation after pre-treatment with vehicle alone (control) or PMA $(1 \mu \mathrm{M} ; 15 \min )$ was determined. In (B(i)), data for control and PMA alone pre-treatment conditions are presented as mean pmol cAMP $\mathrm{mg}^{-1}$ protein \pm S.E.M. $(n=3)$. In (B(ii)) values are shown as normalised data for all conditions including control and PMA pretreatments, and represent mean \pm S.E.M of three independent experiments expressed as $\%$ inhibition of forskolin-stimulated adenylyl cyclase. *Statistical significance at $\mathrm{p}<0.05$ for data compared with respective non-pretreated agonist-induced inhibition of forskolin-stimulated controls (Mann-Whitney U-Test).

\section{Figure 6. Heterologous regulation of $P 2 Y_{12}$ receptor responses by $P 2 Y_{1}$ in platelets activated by}

ADP. Platelets were pretreated with the $\mathrm{P}_{2} \mathrm{Y}_{1}$-selective antagonist A3P5P $(1 \mathrm{mM})$ or with vehicle alone (No pre-treatment) as control. Agonist (ADP; $10 \mu \mathrm{M})$-dependent inhibition of forskolin (1 $\mu \mathrm{M} ; 5 \mathrm{~min})$ stimulated adenylyl cyclase activity by $\mathrm{P} 2 \mathrm{Y}_{12}$ purinergic receptor activation was determined after pretreatment with vehicle alone (control) or a desensitising addition of ADP (10 $\mu \mathrm{M} ; 5 \mathrm{~min})$. In (A), data are 
Molecular Pharmacology Fast Forward. Published on June 27, 2006 as DOI: 10.1124/mol.106.023549

This article has not been copyedited and formatted. The final version may differ from this version.

$\operatorname{MOL}(2006 / 023549)$

presented as percentage inhibition of adenylyl cyclase activity induced by addition of ADP. In (B), data are presented as the percentage desensitisation of the $\mathrm{P} 2 \mathrm{Y}_{12}$ receptor response seen after pre-treatment with ADP. Data are mean \pm S.E.M of three independent experiments. *Statistical significance at $\mathrm{p}<0.05$ for data compared with respective non-pretreated agonist-induced inhibition of forskolin-stimulated controls (Mann-Whitney U-Test).

Figure 7. Surface $\mathrm{P}_{2} \mathrm{Y}_{1}$ and $\mathrm{P}_{2} \mathrm{Y}_{12}$ receptor expression in human platelets is regulated by $\mathrm{PKC}$. In experiments assessing receptor internalization platelets were stimulated with ADP $(10 \mu \mathrm{M})$ or vehicle alone for 5, 10 or 30 minutes. Platelets were incubated with $\left[{ }^{3} \mathrm{H}\right]-2 \mathrm{MeSADP}(100 \mathrm{nM})$ and specific receptor binding determined in the presence of either the $\mathrm{P}_{2} \mathrm{Y}_{1}$ receptor antagonist A3P5P (1 mM; $\left.\mathrm{P} 2 \mathrm{Y}_{1}\right)$, the $\mathrm{P} 2 \mathrm{Y}_{12}$ receptor antagonist AR-C69931MX (1 $\mu \mathrm{M}$; P2Y $\left.{ }_{12}\right)$ or a combination of both antagonists (Both). In (A) platelets were treated with $\mathrm{ADP}(10 \mu \mathrm{M})$ for 10 minutes. Data are expressed as receptor specific $\left[{ }^{3} \mathrm{H}\right]-2 \mathrm{MeSADP}$ binding $\left(\left[{ }^{3} \mathrm{H}\right]-2 \mathrm{MeSADP}\right.$ binding (absence of displacing ligand - presence of displacing ligand) DPM) and represent means \pm S.E.M. of three independent experiments. In (B) platelets were treated with $\operatorname{ADP}(10 \mu \mathrm{M})$ for $0-30$ minutes. Data are expressed as $\%$ surface receptor and represent means \pm S.E.M. of three independent experiments. In $(\mathbf{C}$ and $\mathbf{D})$ platelets were pretreated for 15 minutes with either the non-specific PKC inhibitor GF109203X (2 $\mu \mathrm{M})$, Gö6976 (1 $\mu \mathrm{M})$, which inhibits calciumdependent $\mathrm{PKC}$ isoforms, including $\mathrm{PKC} \alpha$, rottlerin $(10 \mu \mathrm{M})$, a $\mathrm{PKC} \delta$ isoform selective inhibitor In $(\mathbf{C})$ $\mathrm{P} 2 \mathrm{Y}_{1}$ and $\mathrm{P}_{2} \mathrm{Y}_{12}$ surface receptor expression was compared in platelets pretreated with $\mathrm{PKC}$ inhibitors versus non-pretreated controls. Data are expressed as \% increase in surface expression represent means \pm S.E.M. of three independent experiments. In (D) platelets were subsequently challenged for 15 minutes with either ADP $(10 \mu \mathrm{M})$, PMA $(1 \mu \mathrm{M})$ or vehicle alone. Data are expressed as \% loss of surface receptor and represent means \pm S.E.M. of three independent experiments. ${ }^{*} \mathrm{p}<0.05$ for data compared with ADP or PMA treatment without PKC inhibitor (vehicle; Mann Whitney U-test). 
Molecular Pharmacology Fast Forward. Published on June 27, 2006 as DOI: 10.1124/mol.106.023549

This article has not been copyedited and formatted. The final version may differ from this version.

$\operatorname{MOL}(2006 / 023549)$ 
A $\quad{ }^{32} \mathrm{P}$ Autoradiograph

Anti-HA
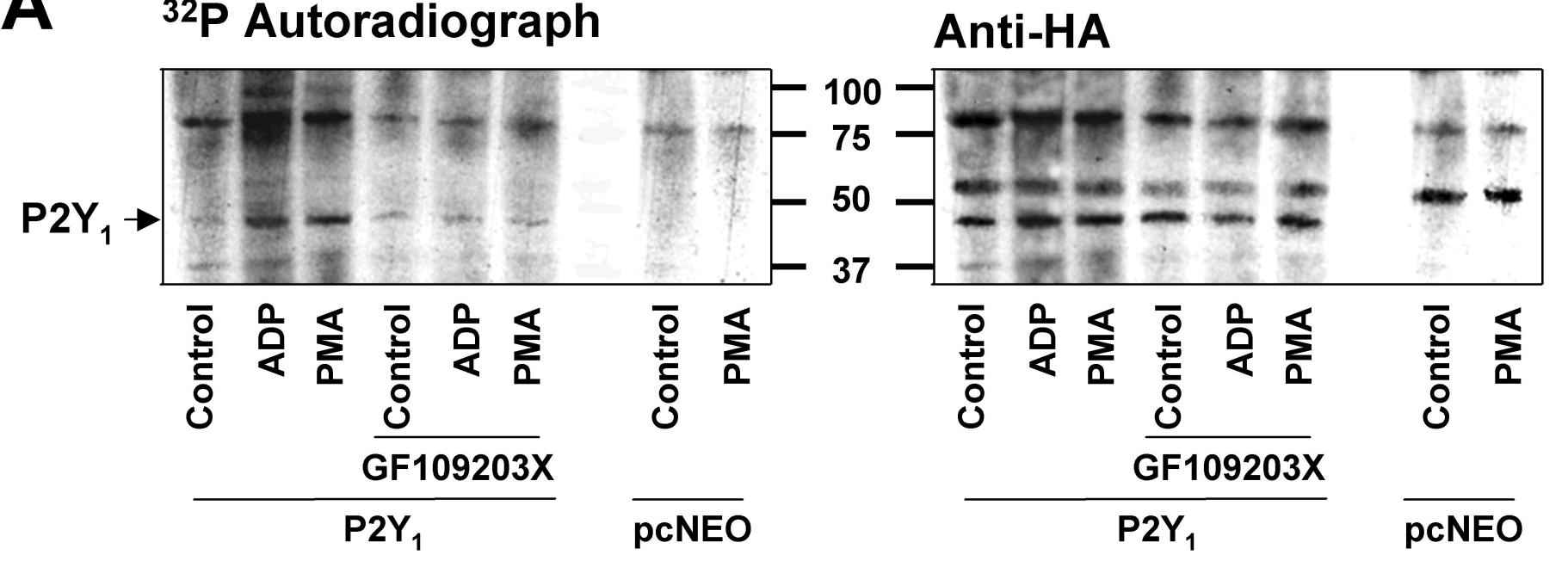

B

${ }^{32} \mathrm{P}$ Autoradiograph

Anti-HA
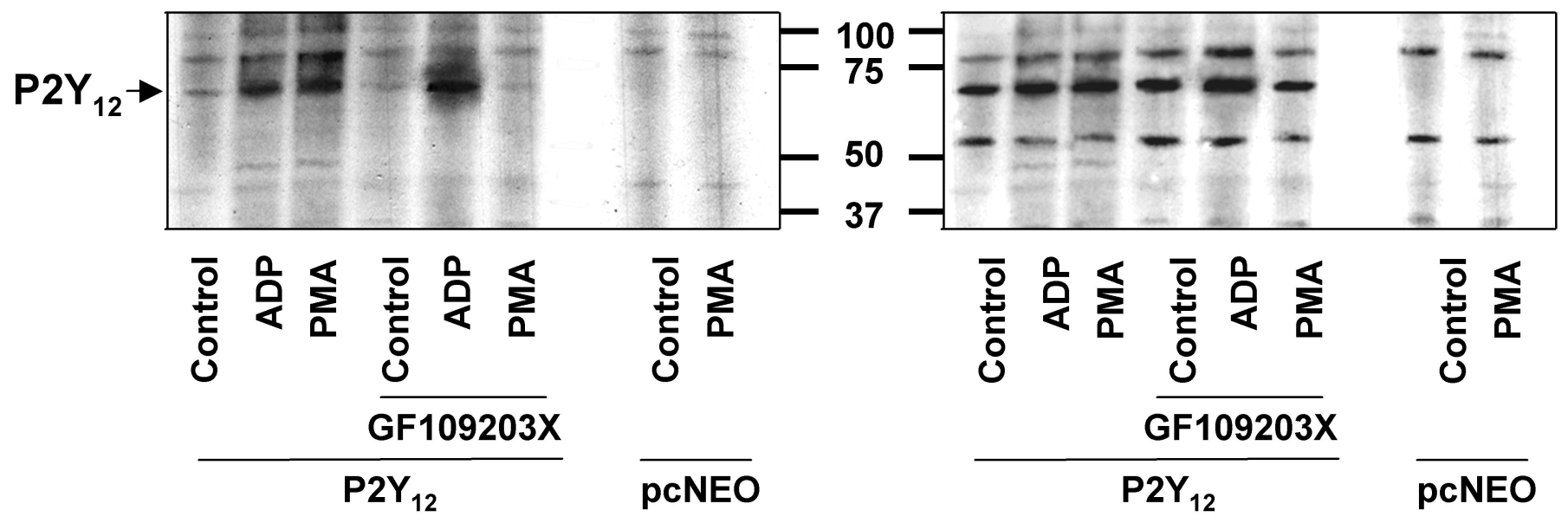

Fig. 1 
A

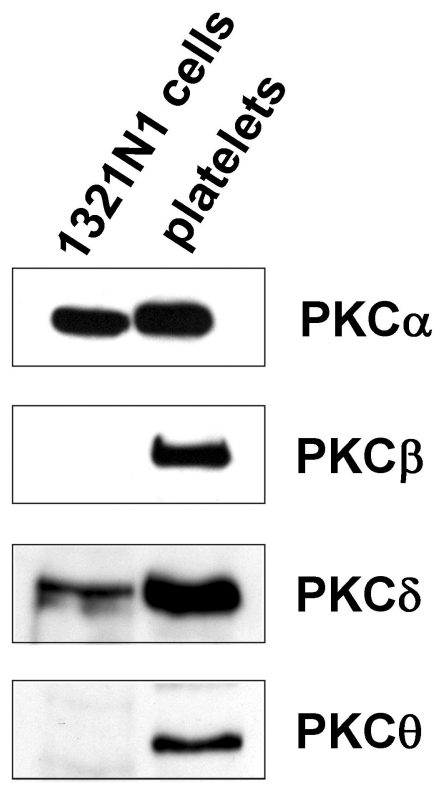

B

PKC $\alpha \rightarrow$

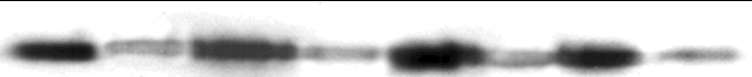

PKC $\delta \rightarrow$

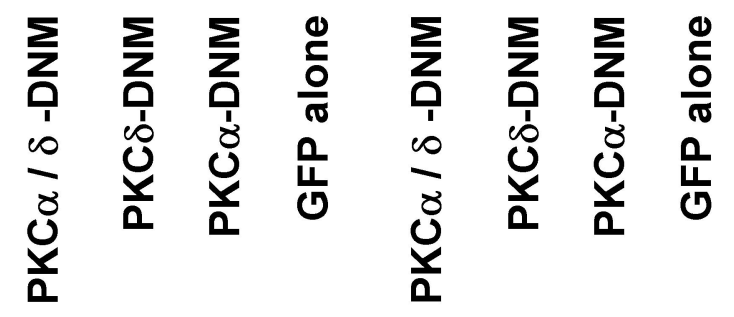

$\mathrm{P} \mathrm{Y}_{12}$

P2Y 1 


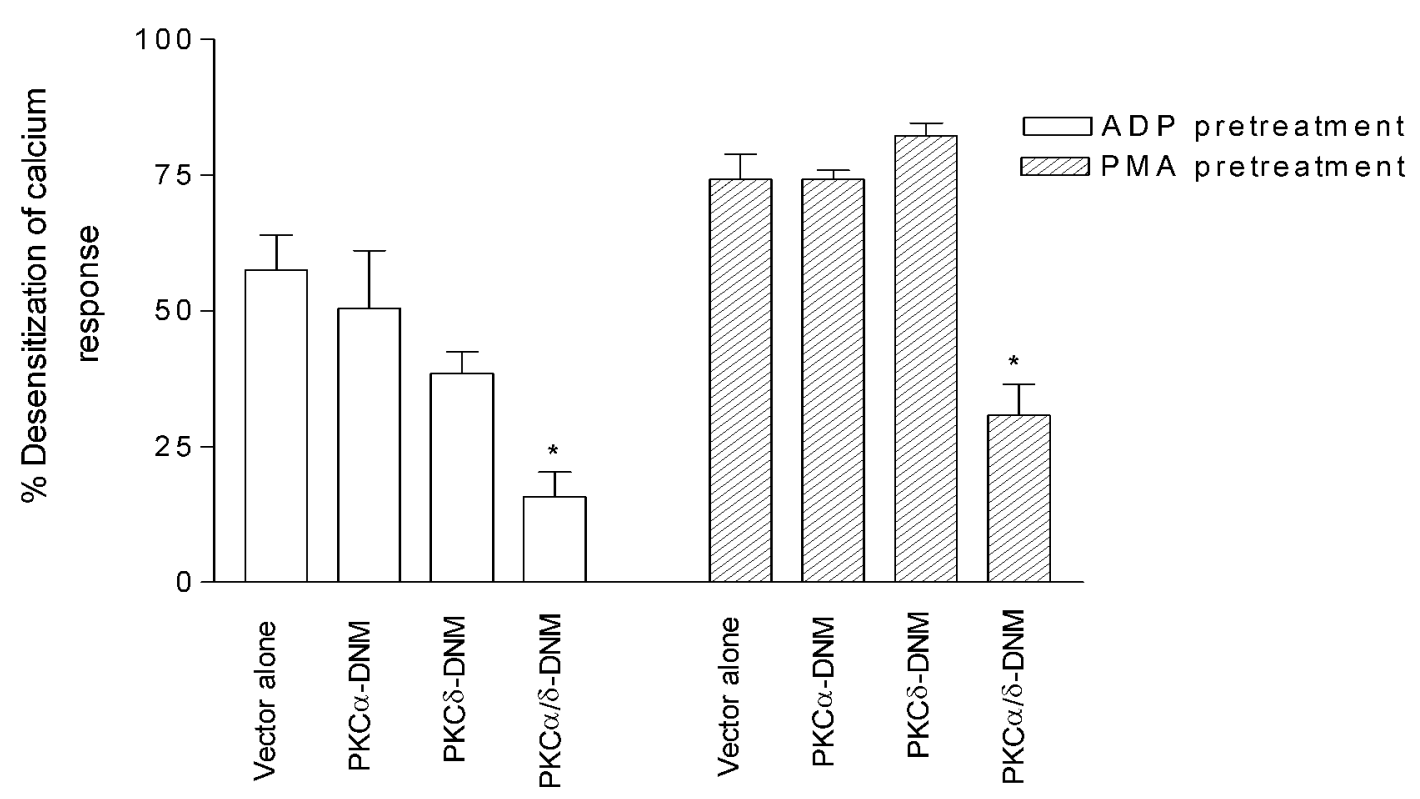

B (i)

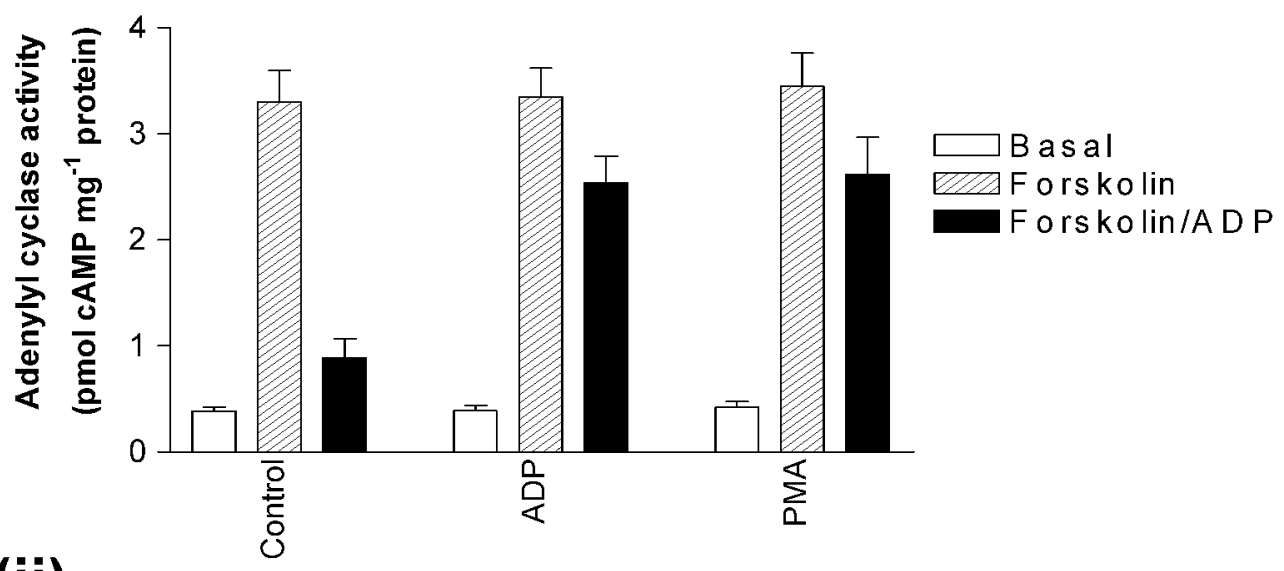

(ii)

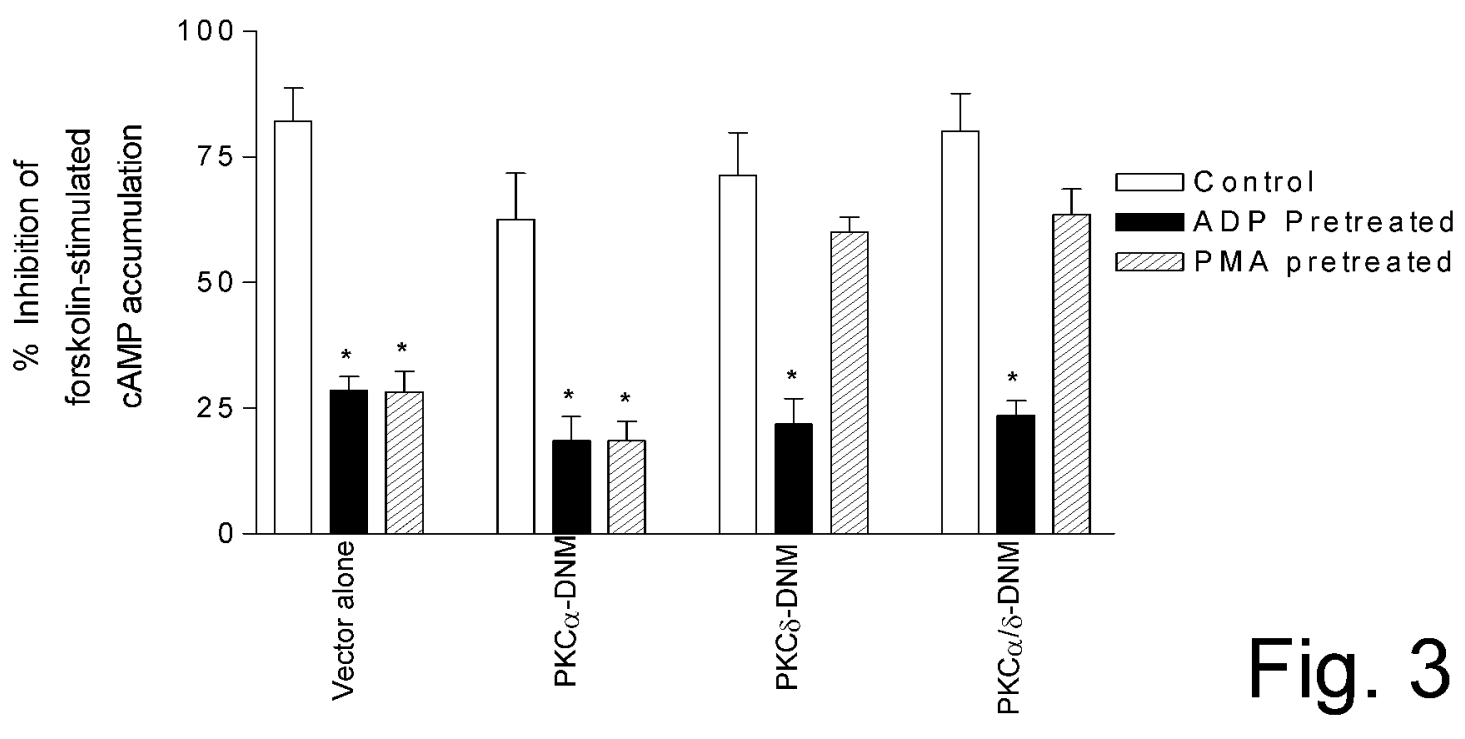




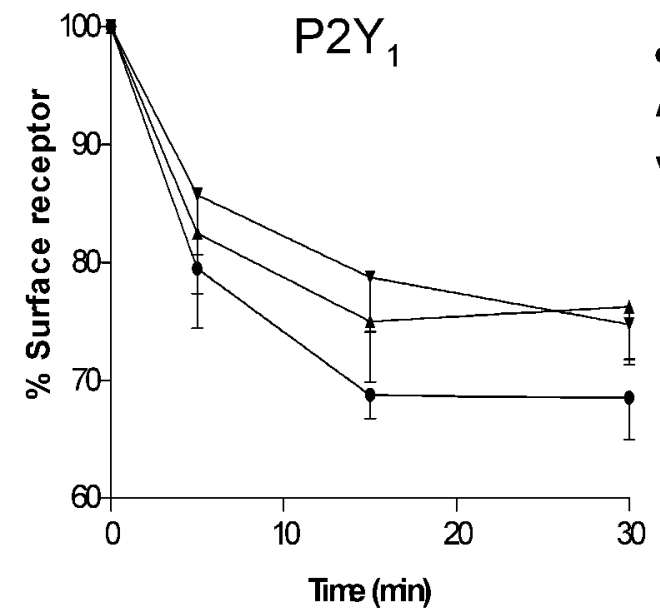

- $A D P$

- PMa

- Carbachol

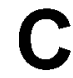

D
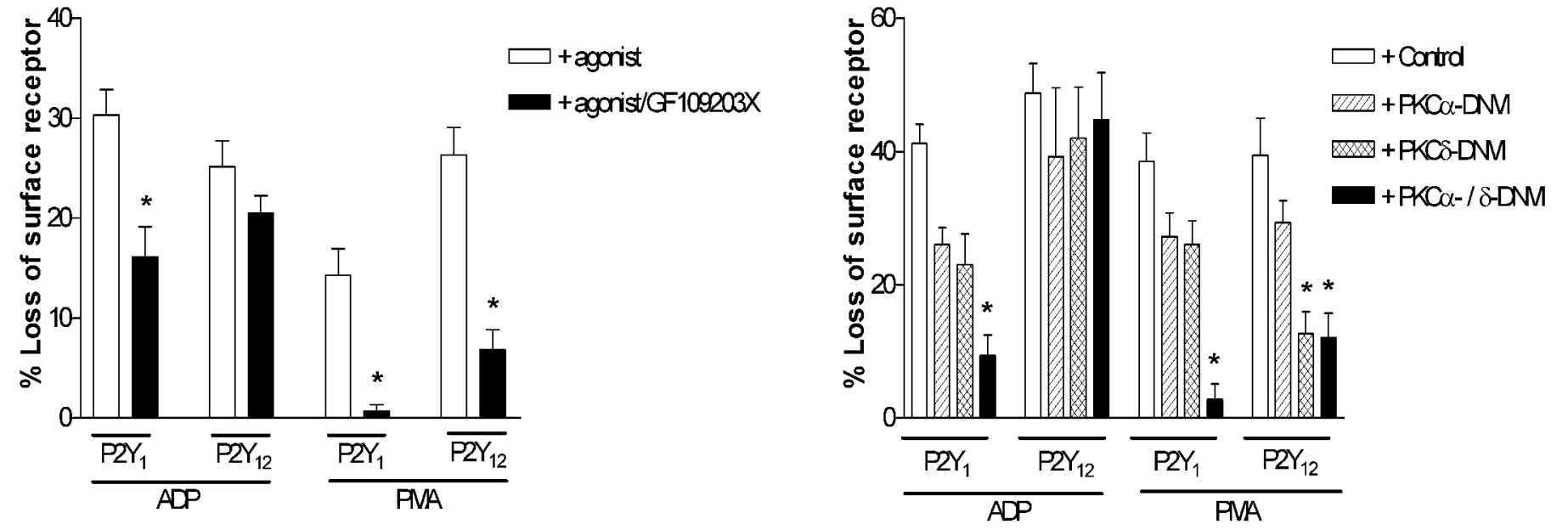

Fig. 4 
A

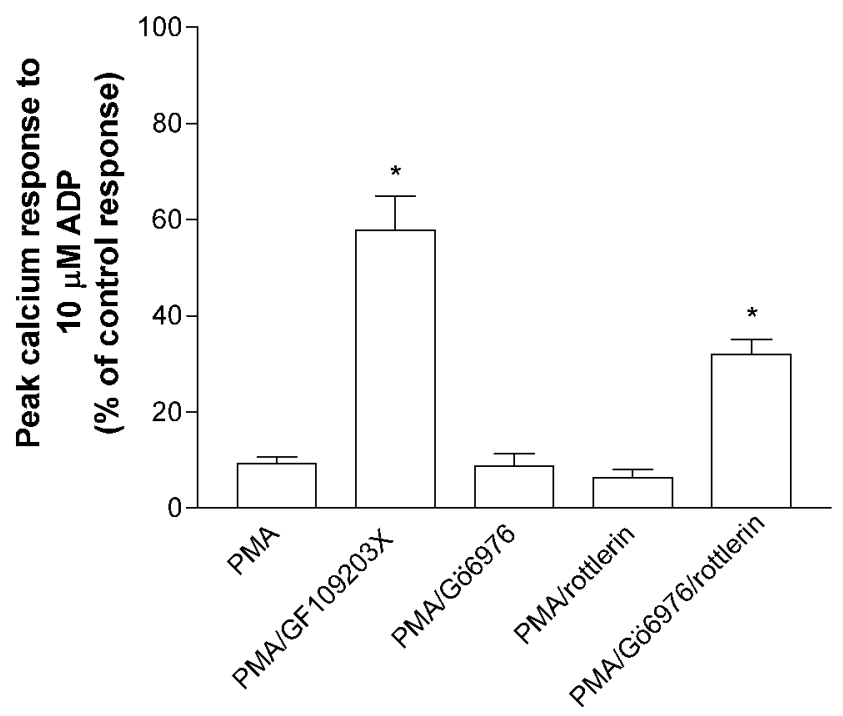

B (i)

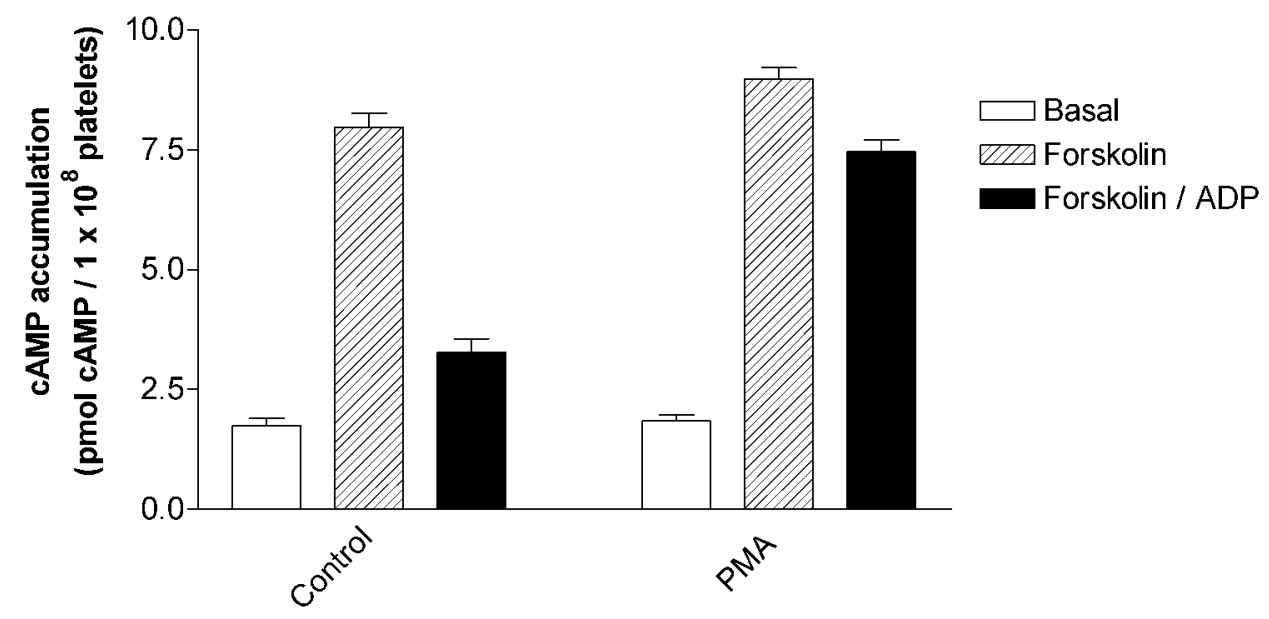

(ii)

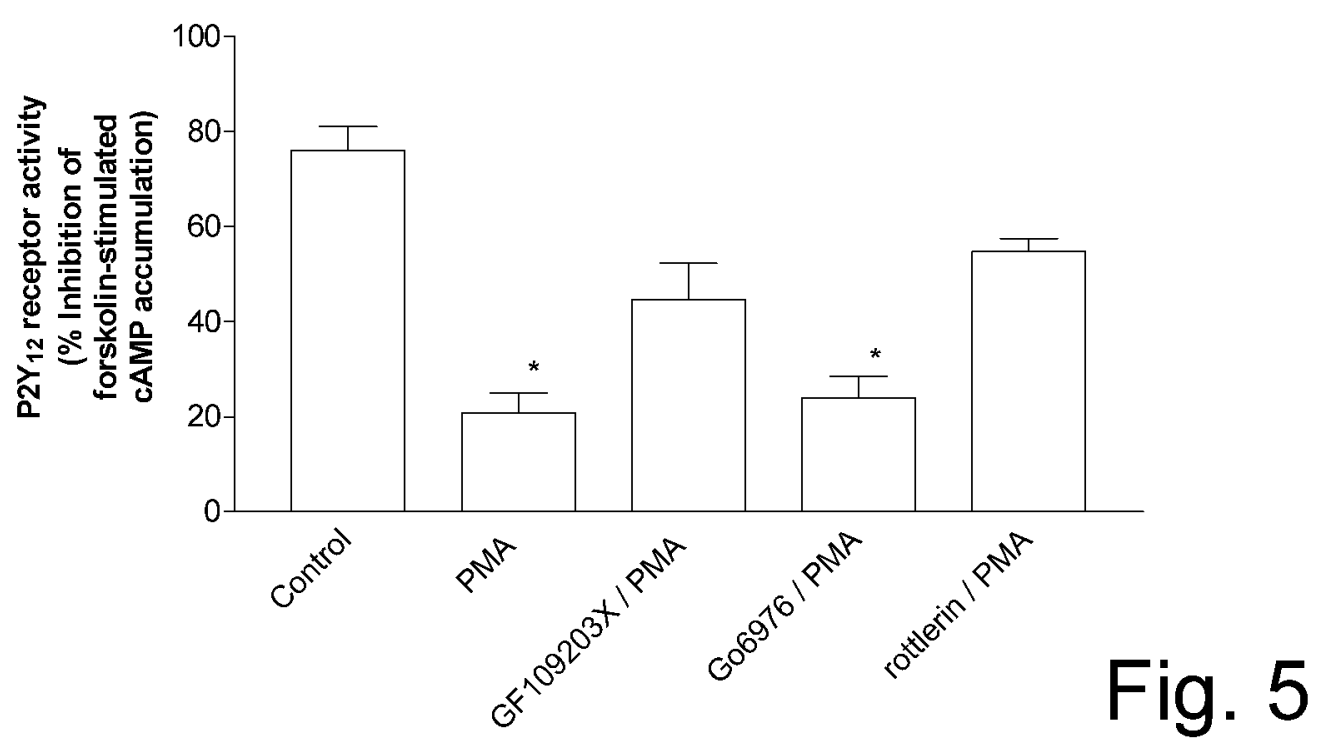




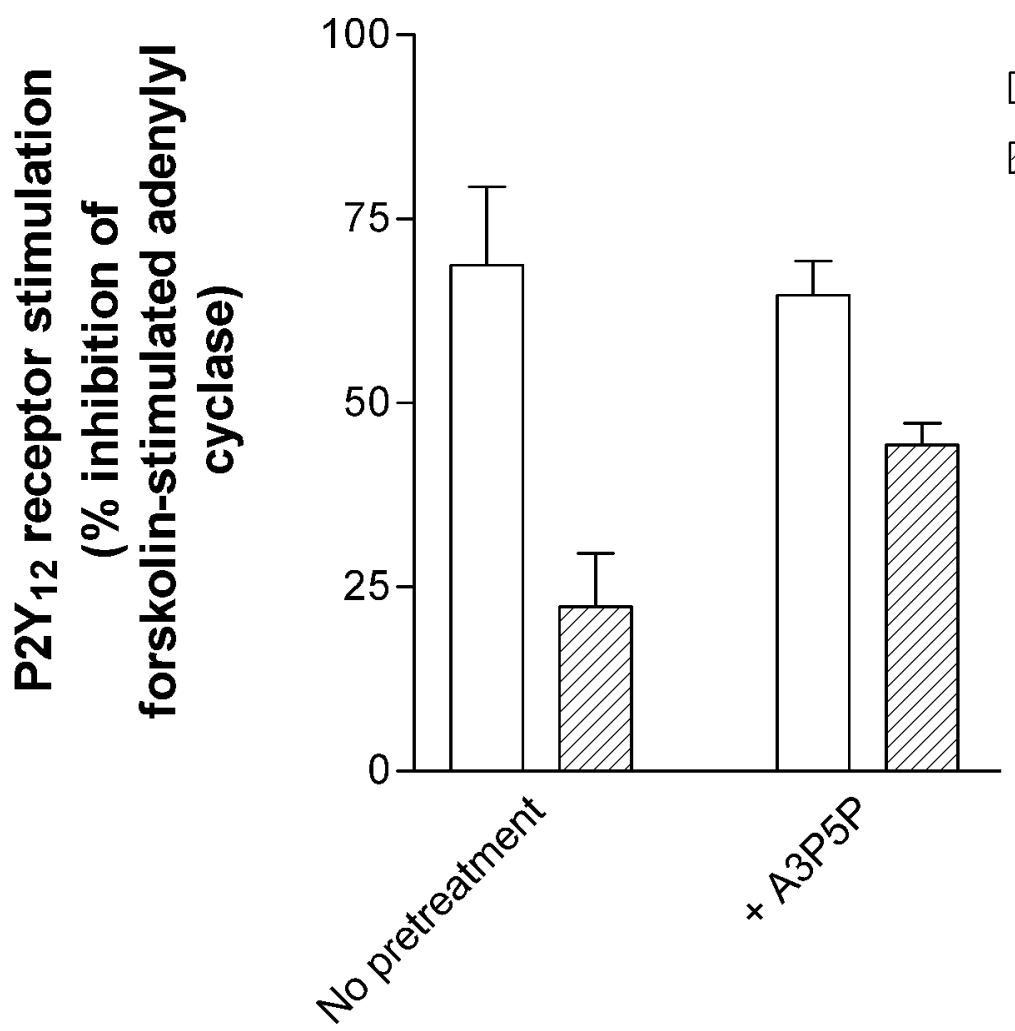

$\square$ Control

ZIIA Desensitized

B

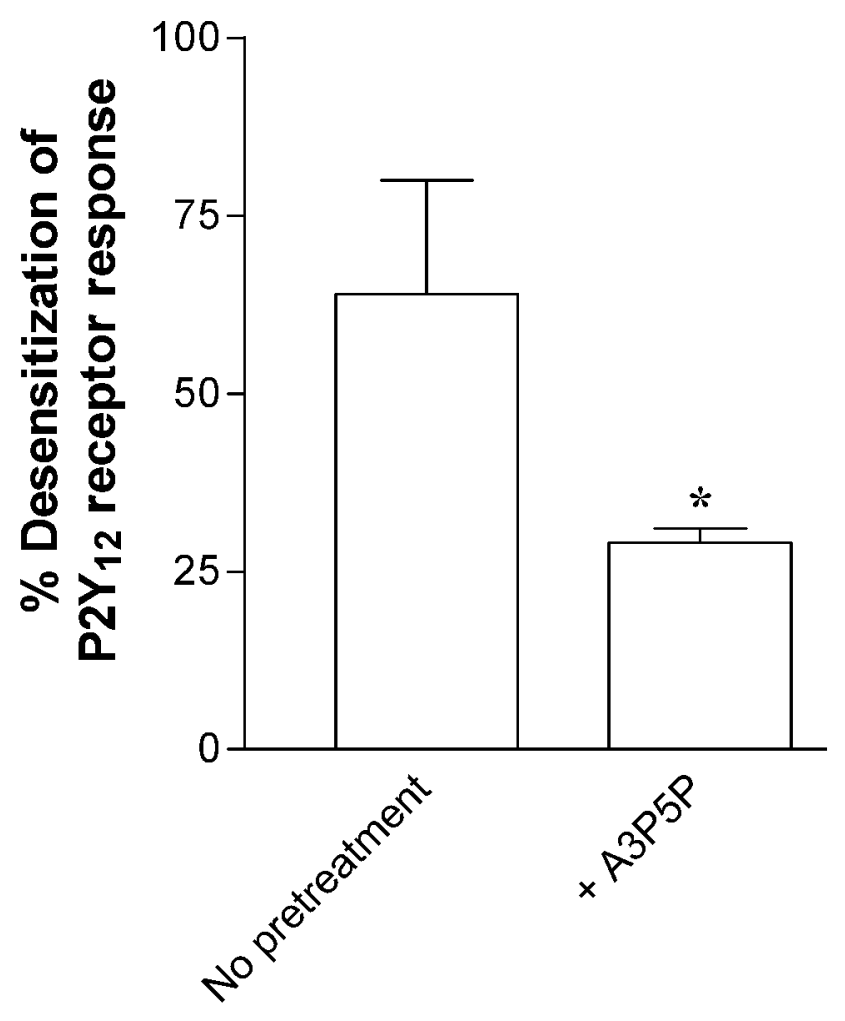


